In cooperation with Arizona Game and Fish Department, Research Branch

\title{
Colorado River Fish Monitoring in Grand Canyon, Arizona-2000 to 2009 Summary
}

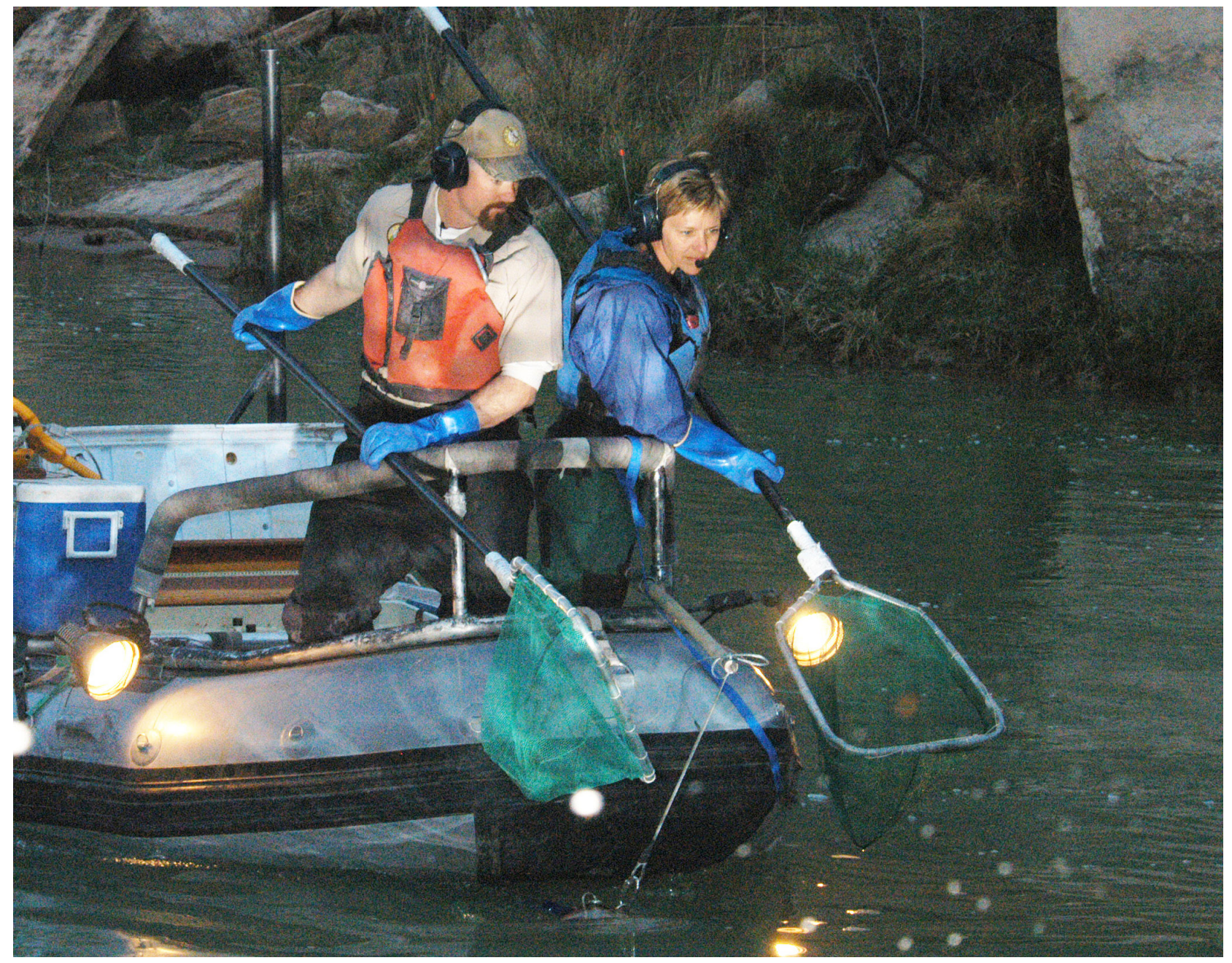

Open-File Report 2010-1246 
Cover: Scientists electrofishing the Colorado River in Grand Canyon. Pictured are (left) R.S. Rogers, Arizona Game and Fish Department and (right) Julie Claussen, volunteer, Illinois Natural History Survey. (Photograph courtesy of George Andrejko, Arizona Game and Fish Department.) 
In cooperation with Arizona Game and Fish Department, Research Branch

\section{Colorado River Fish Monitoring in Grand Canyon, Arizona-2000 to 2009 Summary}

By Andrew S. Makinster, William R. Persons, Luke A. Avery, and Aaron J. Bunch

Open-File Report 2010-1246

U.S. Department of the Interior

U.S. Geological Survey 


\title{
U.S. Department of the Interior \\ KEN SALAZAR, Secretary
}

\author{
U.S. Geological Survey \\ Marcia K. McNutt, Director
}

U.S. Geological Survey, Reston, Virginia 2010

For product and ordering information:

World Wide Web: http://www.usgs.gov/pubprod

Telephone: 1-888-ASK-USGS

For more information on the USGS—-the Federal source for science about the Earth,

its natural and living resources, natural hazards, and the environment:

World Wide Web: http://www.usgs.gov

Telephone: 1-888-ASK-USGS

Suggested citation:

Makinster, A.S., Persons, W.R., Avery, L.A., and Bunch, A.J., 2010, Colorado River fish monitoring in Grand Canyon, Arizona-2000 to 2009 summary: U.S. Geological Survey Open-File Report 2010-1246, 26 p.

Any use of trade, product, or firm names is for descriptive purposes only and does not imply endorsement by the U.S. Government.

Although this report is in the public domain, permission must be secured from the individual copyright owners to reproduce any copyrighted material contained within this report. 


\section{Contents}

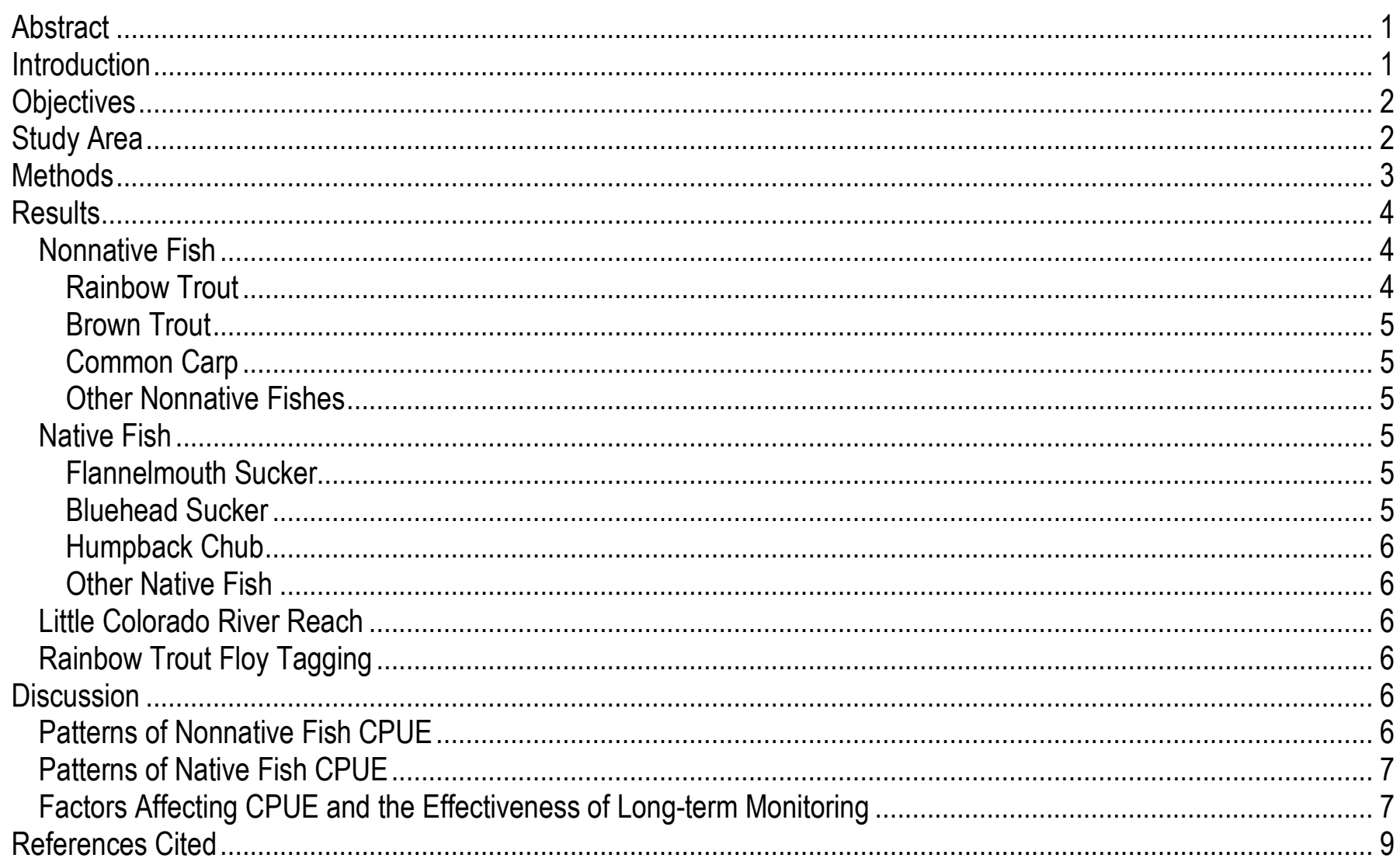

\section{Figures}

1. Map of study area identifying Glen Canyon Dam, Lees Ferry, Lake Mead, and fish reaches.

2. Mean CPUE (catch per hour) of rainbow trout captured during electrofishing surveys on the Colorado River between Lees Ferry and Lake Mead, 2000-2009.

3. Length-frequency distribution of rainbow trout captured during electrofishing surveys on the Colorado River between Lees Ferry and Lake Mead, 2000-2009, all reaches

4. Mean CPUE (catch per hour) of brown trout captured during electrofishing surveys on the Colorado River between Lees Ferry and Lake Mead, 2000-2009.

5. Length-frequency distribution of brown trout captured during electrofishing surveys on the Colorado River between Lees Ferry and Lake Mead, 2000-2009 all reaches

6. Mean CPUE (catch per hour) of common carp captured during electrofishing surveys on the Colorado River between Lees Ferry and Lake Mead, 2000-2009.

7. Length-frequency distribution of common carp captured during electrofishing surveys on the Colorado River between Lees Ferry and Lake Mead, 2000-2009 all reaches.

8. Mean CPUE (catch per hour) of flannelmouth sucker captured during electrofishing surveys on the Colorado River between Lees Ferry and Lake Mead, 2000-2009.

9. Length-frequency distribution of flannelmouth sucker captured during electrofishing surveys on the Colorado River between Lees Ferry and Lake Mead, 2000-2009 all reaches. 
10. Mean CPUE (catch per hour) of bluehead sucker captured during electrofishing surveys on the Colorado River between Lees Ferry and Lake Mead, 2000-2009

11. Length-frequency distribution of bluehead sucker captured during electrofishing surveys on the Colorado River between Lees Ferry and Lake Mead, 2000-2009 all reaches

12. Mean CPUE (catch per hour) of $(A)$ rainbow trout, $(B)$ brown trout, $(C)$ common carp, $(D)$ flannelmouth sucker, and (E) bluehead sucker captured during electrofishing surveys in reach 2 (river mile 56.1-69) of the Colorado River, Grand Canyon, Ariz

\section{Tables}

1. Sampling information and species composition data collected during the first 2009 Arizona Game and Fish Department long-term monitoring trip

2. Sampling information and species composition data collected during the second 2009 Arizona Game and Fish Department long-term monitoring trip 24

3. Mean CPUE (catch-per-unit-effort) and coefficient of variation (CV, \%) for common large-bodied fishes by species and year, all reaches combined, Colorado River 2000-2009 25

4. Recapture information for Floy tagged rainbow trout captured during electrofishing surveys on the Colorado River between Lees Ferry and Lake Mead, 2009

5. Trip information from 2000-2009, including flow (cubic feet per second) at Lees Ferry and temperature $\left({ }^{\circ} \mathrm{C}\right)$ at river mile 87 


\title{
Colorado River Fish Monitoring in Grand Canyon, Arizona-2000 to 2009 Summary
}

\author{
By Andrew S. Makinster, ${ }^{1}$ William R. Persons,${ }^{2}$ Luke A. Avery, ${ }^{1}$ and Aaron J. Bunch ${ }^{1}$
}

\begin{abstract}
Long-term fish monitoring in the Colorado River below Glen Canyon Dam is an essential component of the Glen Canyon Dam Adaptive Management Program (GCDAMP). The GCDAMP is a federally authorized initiative to ensure that the primary mandate of the Grand Canyon Protection Act of 1992 to protect resources downstream from Glen Canyon Dam is met. The U.S. Geological Survey's Grand Canyon Monitoring and Research Center is responsible for the program's long-term fish monitoring, which is implemented in cooperation with the Arizona Game and Fish Department, U.S. Fish and Wildlife Service, SWCA Environmental Consultants, and others. Electrofishing and tagging protocols have been developed and implemented for standardized annual monitoring of Colorado River fishes since 2000. In 2009, sampling occurred throughout the river between Lees Ferry and Lake Mead for 38 nights over two trips. During the two trips, scientists captured 6,826 fish representing 11 species. Based on catch-per-unit-effort, salmonids (for example, rainbow trout (Oncorhynchus mykiss) and brown trout (Salmo trutta)) increased eightfold between 2006 and 2009. Flannelmouth sucker (Catostomus latipinnis) catch rates were twice as high in 2009 as in 2006. Humpback chub (Gila cypha) catches were low throughout the 10 -year sampling period.
\end{abstract}

\section{Introduction}

Long-term fish monitoring in the Colorado River below Glen Canyon Dam (GCD) is an essential component of the Glen Canyon Dam Adaptive Management Program (GCDAMP), a federally authorized initiative to protect and mitigate adverse impacts to resources downstream from the dam. The U.S. Geological Survey's Grand Canyon Monitoring and Research Center is responsible for long-term fish monitoring for the program, which is implemented in cooperation with the Arizona Game and Fish Department, U.S. Fish and Wildlife Service, SWCA Environmental Consultants, and others. Long-term monitoring establishes a "baseline," or antecedent context, through which response of biota to changing management policies or experiments can be interpreted and evaluated (Walters and Holling, 1990; Thomas, 1996; Walters, 1997). For example, since 1996, a series of experimental high flows have been released from GCD as part of a strategy intended to restore sandbars in Grand Canyon, and several stable-flow tests have been conducted to benefit the humpback chub (Gila cypha), a species federally listed as endangered. Between 2003 and 2006, an experimental program that used electrofishing

\footnotetext{
${ }^{1}$ Arizona Game and Fish Department, Research Branch, 5000 W. Carefree Highway, Phoenix, AZ 85035

${ }^{2}$ U.S. Geological Survey, Southwest Biological Science Center, Grand Canyon Monitoring and Research Center, 2255 N. Gemini Drive, Flagstaff, AZ 86001
} 
removed approximately 20,000 nonnative rainbow trout (Oncorhynchus mykiss) from near the mouth of the Little Colorado River. During the same period, water temperatures below GCD increased as drought caused the level of Lake Powell to drop and warmer surface waters were released downstream. Recent management actions include translocating humpback chub to Shinumo Creek in Grand Canyon and installing a fish weir in Bright Angel Creek to remove brown trout (Salmo trutta). Long-term fish monitoring can help managers evaluate the effectiveness of these experiments and policies.

The river between GCD and Lees Ferry (fig. 1) is managed as a rainbow trout sport fishery, but GCDAMP management goals for nonnative fish below Lees Ferry relate to their impact on native species, particularly the humpback chub. The Lees Ferry rainbow trout fishery is a naturally reproducing population, and stocking has not occurred since 1998. Nonnative salmonids (rainbow and brown trout) have increased in abundance in the Colorado River below GCD since the early 1990s (Gloss and others, 2005). These increases in abundance were concurrent with changes in the operation of GCD that included higher minimum, higher mean, and more stable flow releases (McKinney and others, 2001; Gloss and others, 2005). Many researchers have suggested that salmonids limit recruitment of native fishes in Grand Canyon through predation (Minckley, 1991; Valdez and Ryel, 1995; Marsh and Douglas, 1997). Two panels of external experts evaluated the protocols used by the Grand Canyon Monitoring and Research Center and its cooperators to monitor fish, and both reviews recommended long-term monitoring of nonnative fish species that pose risks of predation to Colorado River native fishes in Grand Canyon. ${ }^{3}$

Protocols for standardized annual monitoring of rainbow trout, brown trout, and common carp (Cyprinus carpio) in the Colorado River were developed and implemented (Speas and others, unpub. report, 2003). ${ }^{4}$ Since 2000, we have conducted two fish monitoring trips each year using electrofishing, generally between March and May, in the mainstem Colorado River between Lees Ferry and Lake Mead (fig. 1).

\section{Objectives}

The specific objectives used during monitoring in 2009 (similar to the objectives for previous years) are as follows:

- Describe trends in salmonid and carp catch-per-unit-effort (CPUE; fish per hour) and distribution from 2000 to 2009

- Evaluate electrofishing as a monitoring tool for native fish species

- Measure changes in nonnative fish CPUE near the confluence of the Little Colorado River

- Evaluate the ability to monitor movement and growth of rainbow trout by Floy tagging

\section{Study Area}

All locations in this study are referred to in river miles (RM) below Lees Ferry (Coconino County, north-central Arizona; RM 0), approximately 1 mi upstream of the confluence of the Paria

\footnotetext{
${ }^{3}$ The two expert panels produced reports in 2001 and 2009, respectively, that outlined recommendations for improving the fish monitoring program. These reports are available from the Grand Canyon Monitoring and Research Center by contacting William R. Persons at wpersons@usgs.gov.

${ }^{4}$ Although the U.S. Geological Survey does not typically cite unpublished reports, this report makes reference to several unpublished reports produced by the Arizona Game and Fish Department to provide the reader background information and ensure a complete assessment of fish population trends.
} 
River. $^{5}$ The Colorado River upstream of the sampling area to GCD (approx. $16 \mathrm{mi}$ ) is not included in this study area. Sampling described in this report was conducted between RM 0 and RM 264.8 of the Colorado River in the Grand Canyon. In general, the river ranges in character from numerous large eddy complexes in depositional areas to narrow, deeply incised sections in reaches composed of resistant rock types. Water quality in the river is strongly influenced by hypolimnetic water discharged from GCD near Page, Arizona. Water discharged from GCD is typically clear $(<5$ nephelometric turbidity units; Vernieu, 2009) and cold $\left(8-11^{\circ} \mathrm{C}\right.$; Stanford and Ward 1991; Voichick and Wright, 2007) and has intermediate conductivity (700-900 $\mu \mathrm{S} / \mathrm{cm}$; Vernieu, 2009).

\section{Methods}

We used a sample power program to determine sample sizes and distribution of effort for each species surveyed. The program was developed specifically for this project to maximize estimator precision (Williams and others, 2002). We used variance estimates (coefficient of variation, CV) from existing Grand Canyon fisheries data collected between 2000 and 2004 (Arizona Game and Fish Department and U.S. Geological Survey, unpub. data, 2004) and estimated sample precision of CPUE as a function of sample size and spatial stratification. We utilized a Monte Carlo procedure to estimate the probability of detecting a true temporal population trend given a range of sample sizes. We selected the design in the present study based on its projected level of sampling precision, $\mathrm{CV} \leq 0.10$.

Bootstrapping indicated that changes in CPUE of $20-30 \%$ and $30-40 \%$ for rainbow trout and brown trout, respectively, are detectable between consecutive years, using the current stratified random sample design, provided that we collect 800-900 samples per year (Rogers and Makinster, unpub. report, 2006). We divided the river into 11 reaches and each reach into sub-reaches defined by campsite availability and location of impassable navigational hazards, such as rapids. Start miles on river left and right are randomly assigned within fishable sub-reaches. With few exceptions, shoreline transects were contiguous.

This method of sample site selection was consistent between 2002 and 2009. Sampling between 2002 and 2009 was relatively consistent and was conducted during the spring except in 2007, which included one spring and one fall trip. During 2000, three relatively short trips were conducted, and during 2001 only one sampling trip was conducted. Although trip dates and lengths were different during 2000 and 2001, other sample methods were the same.

In 2009, we conducted two electrofishing trips in the mainstem Colorado River between Lees Ferry and Lake Mead (RM 0 and RM 265). The dates of the two trips were February 28-March 17, 2009, and March 23-April 15, 2009. Daily flow discharge at GCD ranged from 207 to $391 \mathrm{~m}^{3} / \mathrm{s}$ during the first trip and from 185 to $391 \mathrm{~m}^{3} / \mathrm{s}$ during the second trip. We sampled at night with two 16-ft Achilles inflatable sport boats outfitted for electrofishing with a Coeffelt CPS unit; each boat included two netters and one experienced driver. The CPS units applied between 350 and $500 \mathrm{~V}$ and 10 to $15 \mathrm{~A}$ to spherical steel electrodes. Each sample consisted of a single electrofishing pass, approximately $300 \mathrm{~s}$ in duration, along shoreline transects. Transect start and stop coordinates were saved on a Garmin III GPS system and river miles were estimated from a Colorado River map and recorded (Martin and Whitis, 2004).

We recorded total length (TL, in $\mathrm{mm}$ ) of every fish captured, fork length for native fishes, and weight (g) for all fish longer than $100 \mathrm{~mm}$, as long as weather conditions allowed. Floy tagging (Floy

\footnotetext{
${ }^{5}$ The use of river mile has a historical precedent and provides a reproducible method for describing locations along the Colorado River below Glen Canyon Dam. Lees Ferry is the starting point, river mile 0 , with mileage measured for both upstream (-) and downstream.
} 
Tag Company, Seattle, Washington) of rainbow trout began in 2009 to determine if movement and growth could be measured between sampling trips and subsequent annual monitoring trips. Rainbow trout and common carp greater than $199 \mathrm{~mm}$ TL received an individually numbered Floy tag and a left pelvic fin clip (rainbow trout) or a dorsal spine clip (carp). The fin or spine clips served as a secondary mark to estimate tag loss. Brown trout, flannelmouth sucker, and bluehead sucker (Catostomus discobolus) greater than $149 \mathrm{~mm}$ TL and humpback chub greater than $99 \mathrm{~mm}$ TL were implanted with passive integrated transponder (PIT) tags, according to standard protocols for handling fish in Grand Canyon (Ward and Hangsleben, unpub. report, 2009). Although not reported in this study, PIT tags are used by several other Grand Canyon fishery projects, and this monitoring provides the opportunity to implant tags and detect existing tags in captured fishes to inform other research. Brown trout received an adipose fin clip as a secondary mark. All PIT tag numbers were recorded on data sheets and saved in PIT scanners. Scanner files were downloaded and archived to confirm the accuracy data sheets and databases. The data were entered into a Microsoft Access database where quality assurance and quality control using standard software routines were employed. The data were then incorporated into the Grand Canyon Monitoring and Research Center fish database.

The 11 reaches used in the study design were later grouped into five larger reaches in order to obtain adequate sample sizes for trend analysis (fig. 1). Data were reported as CPUE per fish species per reach, with CPUE serving as an index of relative abundance. We report mean CPUE \pm 2 standard errors, which is a close approximation of 95\% confidence intervals (Snedecor and Cochran, 1976). Fish data collected in turbid water may yield confounding results because of different fish-capture probabilities among turbid and clear water samples (Speas and others, 2004); therefore, data collected during turbid water conditions were not included in CPUE analyses. For example, samples that were collected downstream of the Little Colorado River during the first trip in 2009 were excluded from CPUE analyses because of high turbidity. Length-frequency histograms were created for each species at 10 mm size increments.

\section{Results}

During the first monitoring trip in 2009, we completed 439 transects averaging $314 \mathrm{~s}$ each over 18 nights between Lees Ferry and Diamond Creek, capturing 2,632 fish representing seven species (table 1). During the second trip, we completed 528 transects averaging $318 \mathrm{~s}$ each over 20 nights, capturing 4,194 fish representing 11 species (table 2). In all but two cases, we sampled a minimum of 12 sites per night per boat. Extreme wind and rain prohibited sampling on March 29, 2009, and two transects were not completed on April 3, 2009, also for weather-related reasons. Coefficients of variation of mean CPUEs for rainbow trout, carp, flannelmouth sucker, and bluehead sucker were less than 15\% during 2009 sampling (table 3).

\section{Nonnative Fish}

\section{Rainbow Trout}

Mean CPUE of rainbow trout in $2009(63.0 \pm 9.8 \mathrm{fish} / \mathrm{hr})$ was the highest observed since 2000 (48.5 \pm 8.1 fish/hr; fig. 2A). Mean annual CPUE of rainbow trout generally declined from 2000 to 2006, but increased since 2006. Reach-specific mean CPUE of rainbow trout also declined from 2001 to 2006, and the highest catch rates were always in Marble Canyon (reach 1, RM 0-56). The increase was dramatic in 2009, particularly in the Marble Canyon reach $(290.8 \pm 35.5 \mathrm{fish} / \mathrm{hr})$, where there was a twofold increase, driven primarily by a strong 2008 cohort (figs. $2 B$ and 3). CPUE in reach 1 was higher 
than any seen since 2000 (fig. $2 B$ ). During most years, the frequency distributions for rainbow trout length showed a bimodal distribution, with peaks near $150 \mathrm{~mm}$ and $300 \mathrm{~mm}$ TL (fig. 3).

\section{Brown Trout}

Mean CPUE of brown trout showed a river-wide decline from $2000(13.1 \pm 2.7 \mathrm{fish} / \mathrm{hr})$ to 2006 $(0.6 \pm 0.2$ fish $/ \mathrm{hr}$; fig. $4 A)$. However, mean CPUE has increased since 2006 in reach 3 where brown trout CPUE was the highest. Reach 3 includes the confluence with Bright Angel Creek where brown trout spawning has been documented (Maddux and others, 1987; Valdez and Ryel, 1995; Weiss and others, 1998). Mean CPUE for brown trout in 2009 (19.4 \pm 6.0 fish/hr) near Bright Angel Creek was similar to that observed in $2004(16.4 \pm 3.3 \mathrm{fish} / \mathrm{hr})$. A relatively strong 2007 cohort was captured in 2008, with about $40 \%$ of the fish captured being less than $150 \mathrm{~mm}$ TL (fig. 5). This cohort persisted into 2009, with the length-frequency distributions showing a strong mode around $220 \mathrm{~mm}$ TL.

\section{Common Carp}

Mean CPUE of common carp declined from 2003 (5.1 $\pm 0.9 \mathrm{fish} / \mathrm{hr})$ to $2007(1.1 \pm 0.3 \mathrm{fish} / \mathrm{hr})$ and has remained relatively low since that time (fig. 6). Common carp CPUE was highest downriver of Shinumo Creek in reaches $4(2.6 \pm 1.4 \mathrm{fish} / \mathrm{hr})$ and 5 (2.4 $\pm 0.8 \mathrm{fish} / \mathrm{hr})$ but significantly lower than 2003 (fig. 6E, F). From 2000 to 2009, most carp captured were more than $300 \mathrm{~mm}$ TL (fig. 7). Young-of-theyear common carp (fish born within the past year) are not produced until after our spring samples and, therefore, were not collected.

\section{Other Nonnative Fishes}

In addition to the common large-bodied nonnative fish, we captured red shiner (Cyprinella lutrensis; $\mathrm{n}=240$ ), fathead minnow (Pimephales promelas; $\mathrm{n}=151$ ), black bullhead (Ameiurus melas; $\mathrm{n}=1$ ), and channel catfish (Ictalurus punctatus; $\mathrm{n}=1$ ). With the exception of 1 red shiner, all these nonnative fish were captured below Diamond Creek near the inflow to Lake Mead.

\section{Native Fish}

\section{Flannelmouth Sucker}

During 2009, increased abundance of flannelmouth in reach 5 drove an overall increase for the whole river (fig. 8A). Mean CPUE increased slightly for flannelmouth sucker in reach 3 (4.9 \pm 2.2 fish/hr), with a large increase in reach $5(42.8 \pm 6.3 \mathrm{fish} / \mathrm{hr})$, where flannelmouth sucker CPUE was the highest (fig. 8F). Length-frequency analysis from 2003 to 2008 indicated flannelmouth recruitment to adulthood is occurring, while data from previous years (for example, 2000-2002) suggested recruitment was low (fig. 9). Length-frequency analysis for 2009 shows a large new cohort.

\section{Bluehead Sucker}

Mean CPUE for bluehead sucker in 2009 (2.1 $\pm 0.6 \mathrm{fish} / \mathrm{hr})$ remained similar to that observed in 2008 (2.5 $\pm 0.9 \mathrm{fish} / \mathrm{hr}$ ). Catches of this species before 2004 were low (less than $0.3 \mathrm{fish} / \mathrm{hr}$ ), suggesting that our sampling program was not suited for monitoring bluehead sucker CPUE. However, since 2004, higher catches indicate that recruitment to adulthood has occurred, which suggests that, when the species is relatively abundant, they are vulnerable to our electrofishing gear. A cohort of juveniles appeared in 2005 and has recruited successfully into reproductive adults (fig. 11). 


\section{Humpback Chub}

Our long-term electrofishing monitoring program is limited in describing population dynamics of humpback chub relative to other programs (for example, Arizona Game and Fish Department monitoring of the lower 1,200 m of the Little Colorado River and U.S. Fish and Wildlife Service hoopnet monitoring in the Little Colorado River). Previous research has shown humpback chub are not commonly vulnerable to electrofishing (Coggins, 2008). Too few humpback chub were captured to complete CPUE and length-frequency analyses (table 3).

\section{Other Native Fish}

Speckled dace (Rhinichthys osculus) is the only other native fish still found in the Colorado River between GCD and Lake Mead. Speckled dace was the third most common species captured, and most captures were in western Grand Canyon and the inflow to Lake Mead (tables 1, 2). Razorback sucker (Xyrauchen texanus), a Colorado River native fish federally listed as endangered, have been collected in recent years in Lake Mead but have not been confirmed from Grand Canyon since 1984.

\section{Little Colorado River Reach}

Mean CPUE of rainbow trout $(64.4 \pm 10.0$ fish/hr; fig. 12) in the Little Colorado River reach (reach 2) has increased since 2006 and similar to that observed in $2002(63.4 \pm 9.3 \mathrm{fish} / \mathrm{hr}$ ), the year before a nonnative removal project (Coggins, 2008). Brown trout $(0.1 \pm 0.2 \mathrm{fish} / \mathrm{hr})$ and common carp $(0.1 \pm 0.2$ fish/hr) mean CPUEs remain low near the Little Colorado River (fig. 12). However, mean CPUEs of flannelmouth sucker and bluehead sucker increased from 2004 to 2007 (fig. 12).

\section{Rainbow Trout Floy Tagging}

Starting in 2009, rainbow trout over $199 \mathrm{~mm}$ TL were Floy tagged from Lees Ferry to Lake Mead to track movement and growth of adults. Of the 962 new Floy tags that were implanted during the course of the first trip, only three tags were observed during the second trip. The tag returns did not show movement over long distances, and movement was always downstream (table 4).

\section{Discussion}

\section{Patterns of Nonnative Fish CPUE}

Comparison of 2009 monitoring data with previous years identifies an increase in CPUE of salmonids since 2007. Reach 1, Marble Canyon, showed a twofold increase in CPUE (fig. 2B). CPUE for rainbow trout in this reach is the highest seen since the inception of the current long-term monitoring program that began in 2000. This increase may be an indication that mainstem spawning and recruitment are occurring downstream of the sport fishery at Lees Ferry and may also indicate increased immigration from upstream reaches. Length-frequency analysis showed that our sampling is ineffective at detecting young-of-the-year rainbow trout, because our efforts are limited to the spring season. In 2007, on a trip conducted in the fall, we did observe young-of-the-year rainbow trout. Brown trout CPUE has also increased since 2006, particularly in areas near Bright Angel Creek. Length-frequency analysis for brown trout in 2009 showed recruitment of a relatively strong 2007 cohort into the young adult population. With the decrease in mainstem water temperatures in 2006 and the absence of the 
mechanical removal and weir removal projects, it is difficult to determine which events are responsible for the increasing trend in CPUE for rainbow trout and brown trout (Coggins, 2008).

Common carp CPUE was consistently higher in reach 5 than in all other reaches before 2007. Length-frequency analysis suggests that our sampling methods are ineffective at sampling all life stages of common carp.

Low numbers of recaptured rainbow trout could be attributed to a combination of factors - a low proportion of the population was tagged, as well as immediate and gradual tag loss (Fabrizio and others, 1999). Floy tag recaptures should increase with higher numbers of fish tagged; therefore, we expect a higher number of recaptures in the future as more tagged fish are present in the system.

\section{Patterns of Native Fish CPUE}

Flannelmouth sucker trends vary by reach, but, overall, we have observed an increase in flannelmouth sucker CPUE since 2005 (fig. 8A). In reach 4, CPUE remained similar in 2009 as in 2008, and reach 3 experienced an increase in CPUE (figs. $8 D, E$ ). Bluehead suckers followed the same trends as flannelmouth suckers, posting higher CPUEs since 2005. There was no net increase in CPUE of bluehead suckers across the entire monitored section of the Colorado River (fig. 10A). Mainstem electrofishing does not appear to be an effective monitoring technique for humpback chub at current densities.

\section{Factors Affecting CPUE and the Effectiveness of Long-term Monitoring}

GCDAMP stakeholders frequently refer to the nonnative fish removal project of 2003-2006 as a potential benefit to humpback chub, however, we find no definitive effects of either removal or temperature change on native fish populations because the removal coincided with an increase in water temperatures throughout the monitored sections of the Colorado River (Voichick and Wright, 2007; Coggins, 2008; Coggins and Walters, 2009; Andersen and others, 2010). The changes in native fish populations are correlated with both nonnative removals and temperature changes; we hypothesize that both factors contributed to the increase in CPUE of flannelmouth sucker and bluehead sucker. In addition, tributary conditions, especially in the Little Colorado River, may have a strong influence on native fish recruitment. The removal of nonnative fish probably reduced predation on young-of-the-year and juvenile native fish, while increased water temperature likely increased spawning success and recruitment of native fish. Higher water temperatures may have allowed increased growth rates of native fishes throughout the mainstem Colorado River, especially in the western portion of Grand Canyon. While managers currently have no control over water temperatures, nonnative fish removals may continue to occur, making it possible in the future to separate the influences of these two factors.

The sampling design used for long-term monitoring since 2002 was originally established to detect riverwide population trends for common large-bodied, nonnative fishes. This sampling design (N $>800$ samples/yr) appears to be adequate for monitoring salmonid and common carp populations in the Grand Canyon and for monitoring the native flannelmouth sucker, which is indicated by the low CV percentages (table 3). The number of samples taken in $2000(\mathrm{~N}=413)$ and $2001(\mathrm{~N}=234)$ was inadequate to capture the status and trends of the nonnative fishes in question. The sampling design used since 2002 appears to be working well, and the level of effort appears to be appropriate for monitoring the most abundant fish in the Grand Canyon segment of the Colorado River. Coggins (2008) found a tight linkage between CPUE and abundance for rainbow trout in Grand Canyon.

Values of CPUE can serve as an index to inform our understanding of population changes, but changes in CPUE over time may not correspond to actual changes in population, because CPUE can be biased by factors that affect capture probabilities (for example, fish species, densities, size, and 
sampling conditions; Williams and others, 2002). Sampling conditions such as water velocity, depth, temperature, and turbidity are variables that affect CPUE in the Colorado River. There is inherent variability in depth and velocity in different habitats sampled. For example, fish likely have a higher capture probability in slow-moving eddies, while capture probability is likely lower in high-velocity riffles. Depth and velocity may also be influenced by water discharge from dam operations; however, discharge rates have remained relatively consistent since 2000 (table 5). Speas and others (2004) found that salmonids in Grand Canyon had higher catchability in turbid water. The bias associated with turbidity was alleviated by removing turbid water samples from the analysis.

Coggins (2008) recommended periodic depletion sampling to obtain better estimates of catchability coefficients, and we recommend that depletion samples be incorporated into future longterm monitoring efforts. Potential biases in CPUEs are likely consistent from year to year as a result of our randomized sample design, little change in water-quality conditions, and relatively little change in size of fish sampled. Therefore, trends in relative fish abundance indexed by CPUE for common, largebodied species should be reliable indicators of population change for managers.

Evaluating localized management actions, such as a mechanical removal of nonnative species in the Little Colorado River reach (reach 2), requires more intensive sampling than long-term monitoring permits and addresses a different question about fisheries resources. If such evaluation is desired by managers, the extensive sampling that occurred in the Little Colorado River and Bright Angel Creek reaches from 2003 to 2006 (during the mechanical removal years and years when a weir was operational) is indicative of the effort necessary to detect impacts of such management actions on a localized scale. However, mechanical reduction of salmonid numbers in the Little Colorado River reach and corresponding lower CPUE will reduce the ability to detect change in this reach with our long-term monitoring sampling design.

Rainbow trout, brown trout, and common carp CPUEs in the Little Colorado River reach were similar to that observed in the early years of the mechanical removal. Likely explanations for these observations are mainstem spawning upstream of the reach and subsequent immigration (rainbow trout), upstream movement and immigration from the lower reaches (brown trout), and spawning activity in the Little Colorado River (common carp). These species also may have benefited from the increased water temperature during 2004-2006.

To assure usable data, this monitoring program must maintain a consistent monitoring protocol. If monitoring designs are compromised to answer short-term questions, the effectiveness of the overall monitoring program is lost. Localized questions or questions on a timespan shorter than 5 years require additional, separate efforts beyond those outlined for long-term monitoring. Consistent, long-term monitoring is essential to evaluate the Glen Canyon Dam Adaptive Management Program. 


\section{References Cited}

Andersen, M.E., Ackerman, M.W., Hilwig, K.D., Fuller, A.E., and Alley, P.D., 2010, Evidence of young humpback chub overwintering in the mainstem Colorado River, Marble Canyon, Arizona, U.S.A.: The Open Fish Science Journal: v. 3, p. 42-50, accessed June 21, 2010, at http://www.bentham.org/open/tofishsj/openaccess2.htm.

Coggins, L.G., Jr., 2008, Active adaptive management for native fish conservation in the Grand Canyon-Implementation and evaluation: Gainesville, University of Florida, Ph.D. dissertation, 173 p.

Coggins, L.G., Jr., and Walters, C., 2009, Abundance trends and status of the Little Colorado River population of humpback chub-An update considering data from 1989-2008: U.S. Geological Survey Open-File Report 2009-1075, 18 p.

Fabrizio, M.C., Nichols, J.D., Hines, J.E., Swanson, B.L., and Schram, S.T., 1999, Modeling data from double-tagging experiments to estimate heterogeneous rates of tag shedding in lake trout (Salvelinus namaycush): Canadian Journal of Fisheries and Aquatic Science, v. 56, p. 1409-1419.

Gloss, S., Lovich, J.E., and Melis, T.S., eds., 2005, The state of the Colorado River ecosystem in Grand Canyon: U.S. Geological Survey Circular 1282, 220 p., accessed on July 14, 2010, at http://pubs.usgs.gov/circ/1282/.

Maddux, H.R., Kubly, D.M., deVos, J.C., Jr., Persons, W.R., Staedicke, R., and Wright, R.L., 1987, Effects of varied flow regimes on aquatic resources of Glen and Grand Canyons-Final report: Phoenix, Arizona Game and Fish Department, submitted to Bureau of Reclamation, Glen Canyon Environmental Studies, contract no. 4-AG-40-01810, 291 p. [Available from National Technical Information Service, Springfield, Va., as NTIS Report PB88-183439/AS.]

Marsh, P.C., and Douglas, M.E., 1997, Predation by introduced fishes on endangered humpback chub and other native species in the Little Colorado River, Arizona: Transactions of the American Fisheries Society, v. 126, p. 343-346.

Martin, T., and Whitis, D., 2004, Guide to the Colorado River in the Grand Canyon: Flagstaff, Ariz., Vishnu Temple Press, [108] p.

McKinney, T., Speas, D.W., Rogers, R.S., and Persons, W.R., 2001, Rainbow trout in a regulated river below Glen Canyon Dam, Arizona, following increased minimum flows and reduced discharge variability: North American Journal of Fisheries Management, v. 21, no. 1, p. 216-222.

Minckley, W.L., 1991, Native fishes of the Grand Canyon Region-An obituary?, in National Academy of Sciences, ed., Colorado River Ecology and Dam Management, Proceedings of a Symposium May 24-25, 1990, Santa Fe, New Mexico: Washington, D.C., National Academy Press, p. 124-177.

Rogers, S.R., and Makinster, A., 2006, Grand Canyon non-native fish monitoring 2003 annual report. Unpublished report submitted to USGS Grand Canyon Monitoring and Research Center January 2006 by Arizona Game and Fish Department, Flagstaff, Ariz., 39 p. [Available from the Arizona Game and Fish Department at http://www.azgfd.gov/w_c/documents/CORdownstreamannualreport2003.pdf.]

Snedecor, G.W., and Cochran, W.G., 1976, Statistical methods: Ames, The Iowa State University Press, $593 \mathrm{p}$.

Speas, D.W., Ward, D.L., Rogers, R.S., and Persons, W.R., 2003, Salmonid population size, relative density and distribution in the Colorado River in Grand Canyon during 2001 with reference to sampling designs for long term monitoring. Unpublished annual report submitted to Grand Canyon Monitoring and Research Center: Phoenix, Arizona Game and Fish Department, 39 p. [Available from the Grand Canyon Monitoring and Research Center by contacting William R. Persons at wpersons@usgs.gov.] 
Speas, D.W., Walters, C.J., Ward, D.L., and Rogers, R.S., 2004, Effects of intraspecific density and environmental variables on electrofishing catchability of brown and rainbow trout in the Colorado River: North American Journal of Fisheries Management, v. 24, p. 586-596.

Stanford, J.A., and Ward, J.V., 1991, Limnology of Lake Powell and the chemistry of the Colorado River, in National Research Council, Colorado River ecology and dam management: National Academy Press, p. 75-101.

Thomas, L., 1996, Monitoring long-term population change-Why are there so many analysis methods?: Ecology, v. 77, p. 49-58.

Valdez, R.A., and Ryel, R.J., 1995, Life history and ecology of the humback chub (Gila cypha) in the Colorado River, Grand Canyon, Arizona. Unpublished report to the Bureau of Reclamation, contract no. 0-CS-40-09110, technical report no. TR-250-08: Logan, Utah, BIO/WEST, Inc., 329 p. [Available from the Grand Canyon Monitoring and Research Center by contacting William R. Persons at wpersons@usgs.gov.]

Vernieu, W.S., 2009, Physical and chemical data for water in Lake Powell and from Glen Canyon Dam releases, Utah-Arizona, 1964-2008: U.S. Geological Survey Data Series 471, 23 p.

Voichick, N., and Wright, S.A., 2007, Water-temperature data for the Colorado River and tributaries between Glen Canyon Dam and Spencer Canyon, northern Arizona, 1988-2005: U.S. Geological Survey Data Series 251, 24 p.

Walters, C.J., 1997, Challenges in adaptive management of riparian and coastal ecosystems: Conservation Ecology, v. 1, no. 2, accessed on July 7, 2010 at http://consecol.org/vol1/iss2/art1.

Walters, C.J., and Holling, C.S., 1990, Large-scale management experiments and learning by doing: Ecology, v. 71, no. 6, p. 2060-2068.

Ward, D., and Hangsleben, M. 2009, Standardized methods for handling fish in Grand Canyon research. Unpublished report submitted to Grand Canyon Monitoring and Research Center: Flagstaff, Arizona Game and Fish Department, 30 p. [Available from the Grand Canyon Monitoring and Research Center by contacting William R. Persons at wpersons@usgs.gov.]

Weiss, S.J., Otis, E.O., and Maughan, O.E., 1998, Spawning ecology of flannelmouth sucker, Catostomus lattipinnis (Catostomidae), in two small tributaries of the lower Colorado River: Environmental Biology of Fishes, v. 52, 419-433 p.

Williams, B.K., Nichols, J.D., and Conroy, M.J., 2002, Analysis and management of animal populations-Modeling, estimation, and decision making: San Diego, Calif., Academic Press, 817 p. 


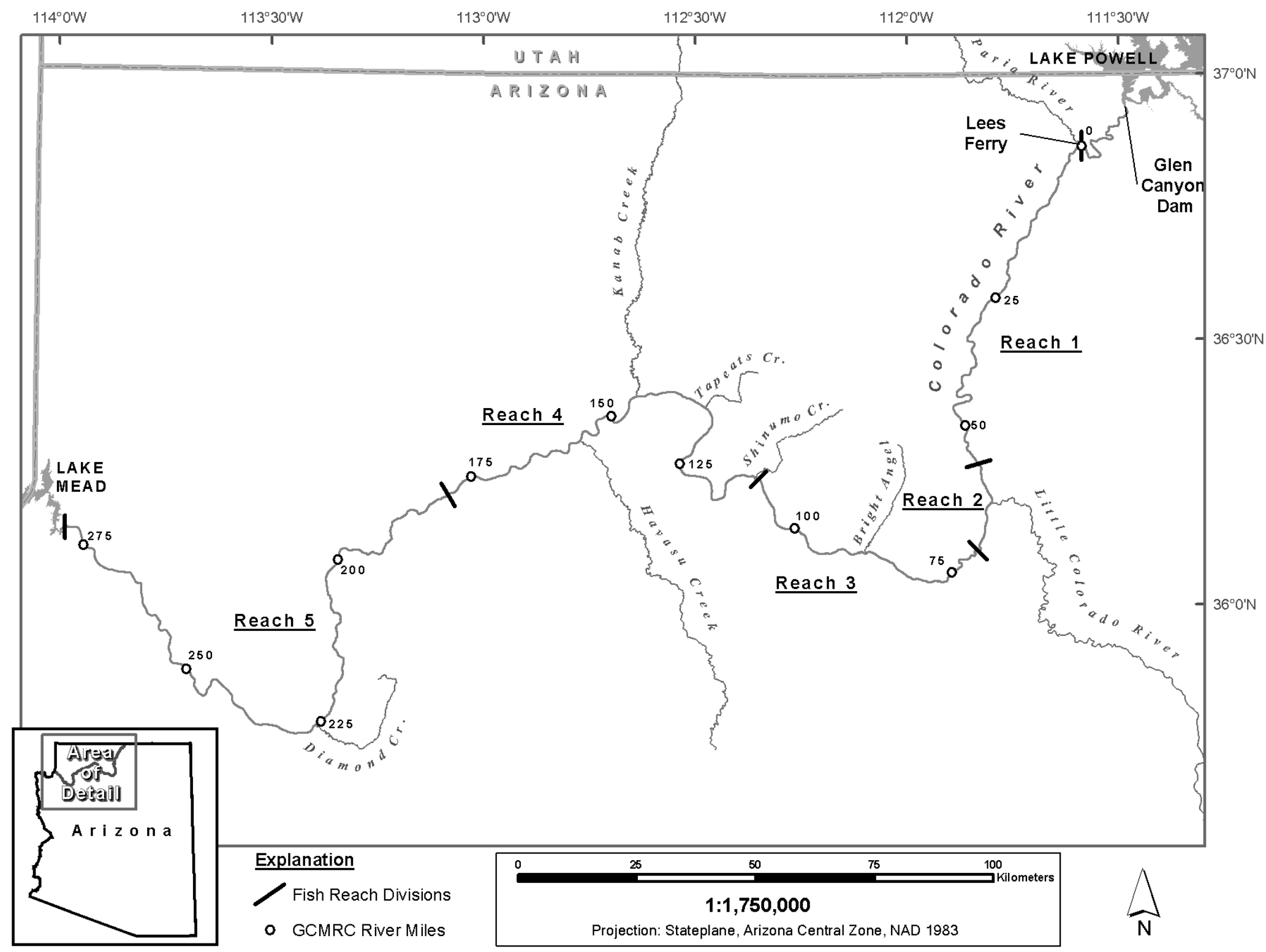

Figure 1. Map of study area identifying Glen Canyon Dam, Lees Ferry, Lake Mead, and fish reaches. River miles starting at Lees Ferry are listed in 25-mile segments. 

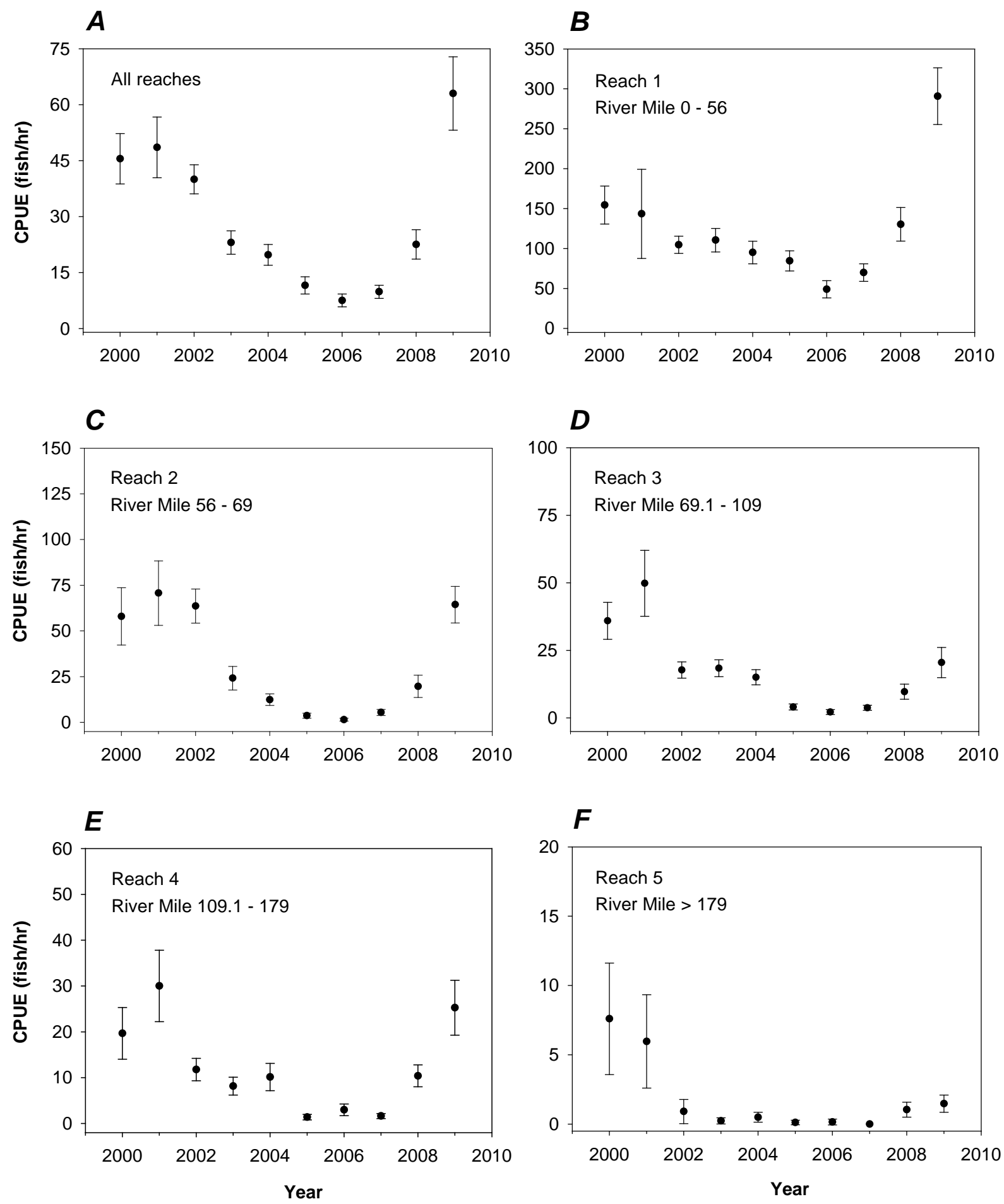

Figure 2. Mean CPUE (catch per hour) of rainbow trout captured during electrofishing surveys on the Colorado River between Lees Ferry and Lake Mead, 2000-2009. A, All reaches. B, Reach 1. C, Reach 2. D, Reach 3. E, Reach 4. $F$, Reach 5. Bars represent \pm 2 standard errors of the mean (close approximation of $95 \%$ confidence intervals). 

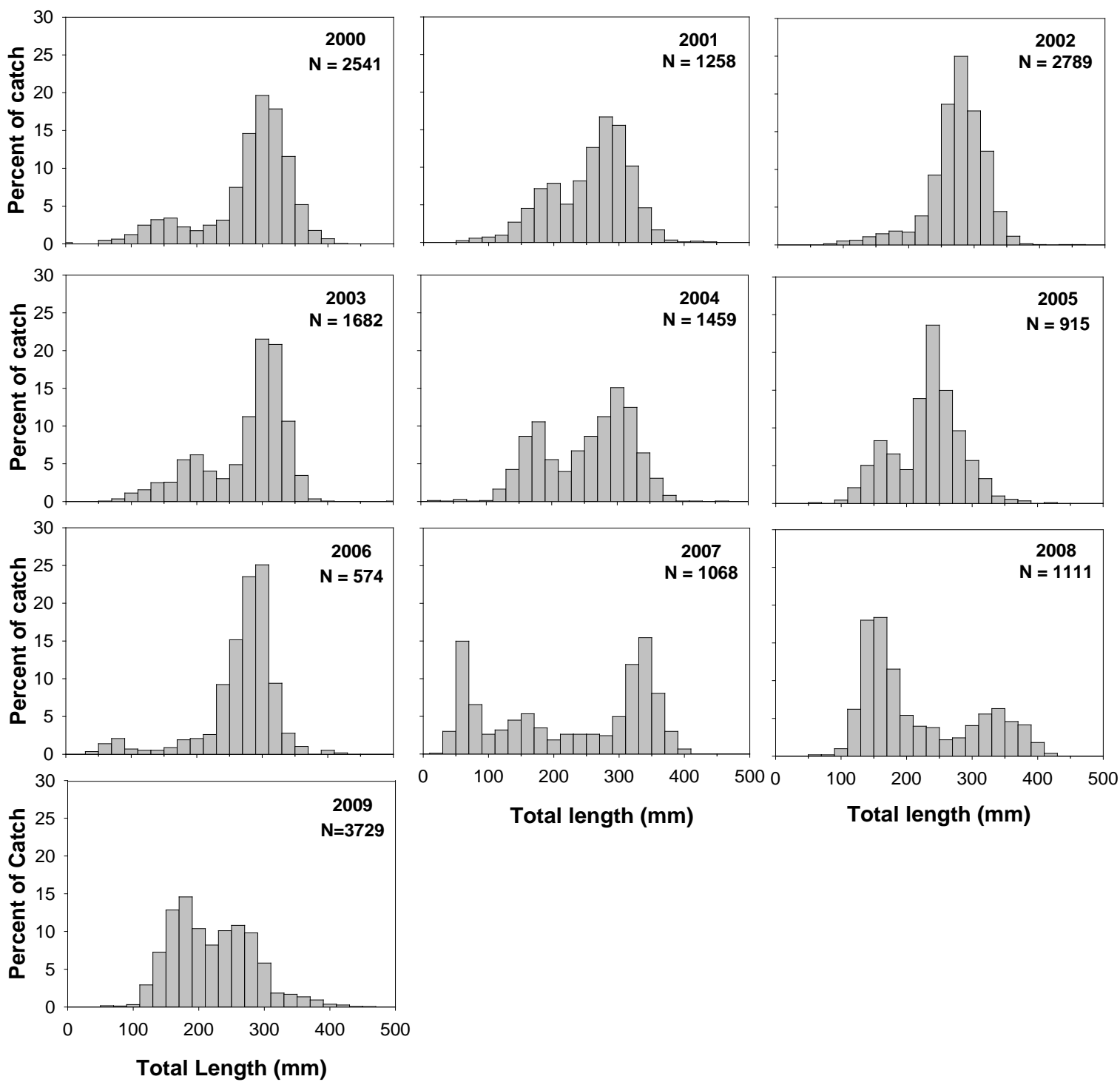

Figure 3. Length-frequency distribution of rainbow trout captured during electrofishing surveys on the Colorado River between Lees Ferry and Lake Mead, 2000-2009, all reaches. 

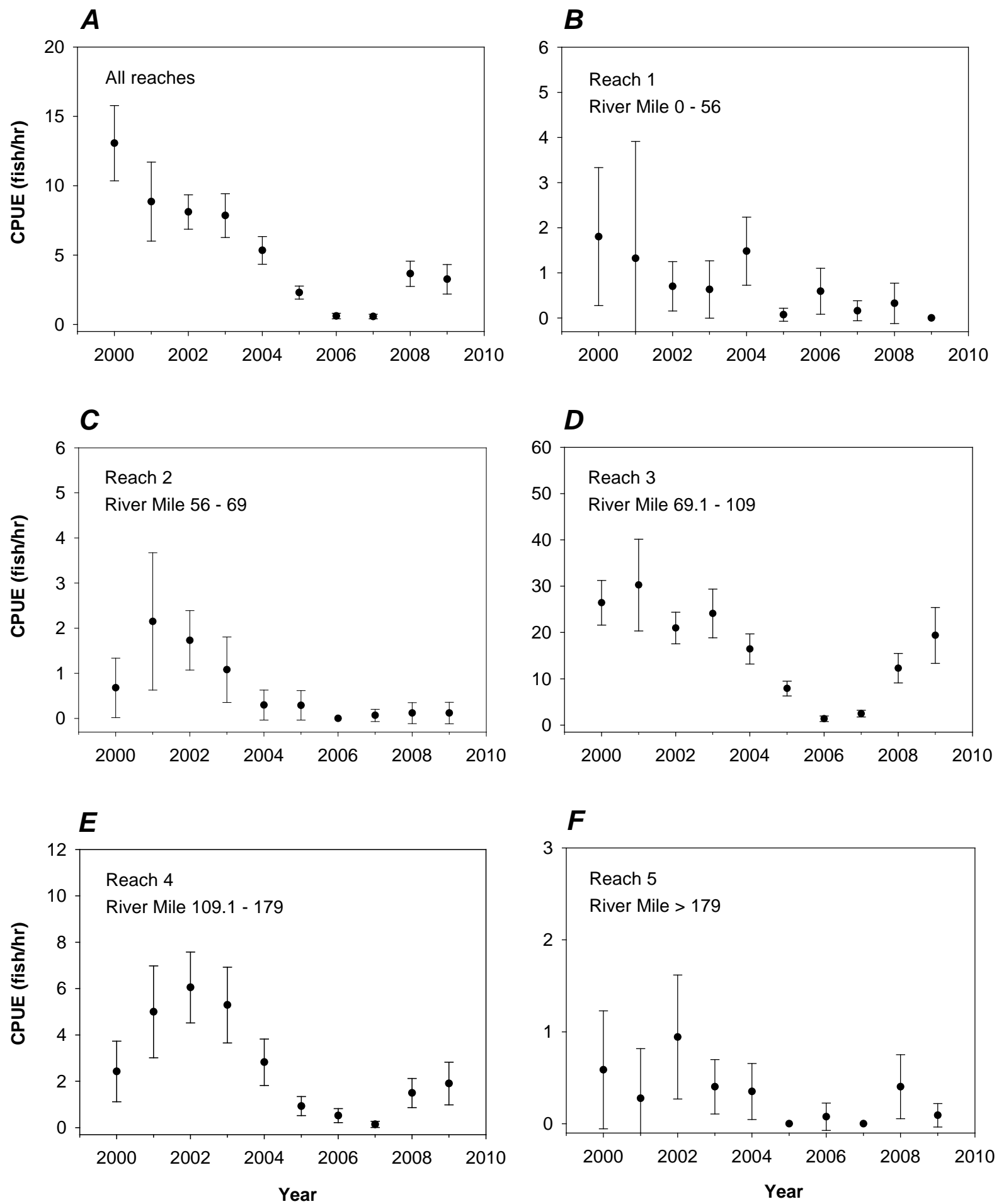

Figure 4. Mean CPUE (catch per hour) of brown trout captured during electrofishing surveys on the Colorado River between Lees Ferry and Lake Mead, 2000-2009. A, All reaches. B, Reach 1. C, Reach 2. D, Reach 3. E, Reach 4. $F$, Reach 5. Bars represent \pm 2 standard errors of the mean (close approximation of $95 \%$ confidence intervals). 

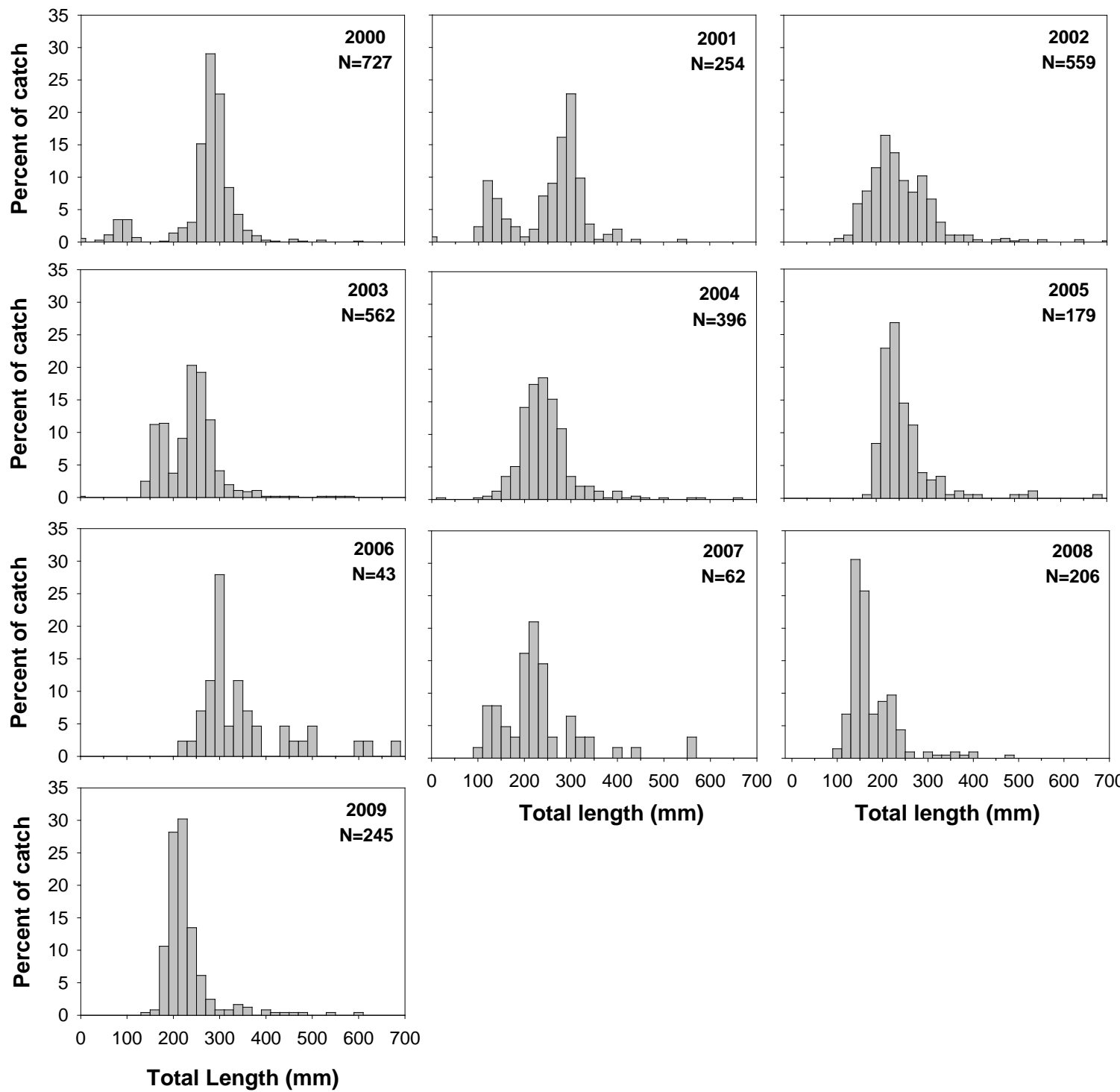

$\begin{array}{llllllllllllllll}0 & 100 & 200 & 300 & 400 & 500 & 600 & 700 & 0 & 100 & 200 & 300 & 400 & 500 & 600 & 700\end{array}$ Total length $(\mathrm{mm})$

Total length $(\mathrm{mm})$

Figure 5. Length-frequency distribution of brown trout captured during electrofishing surveys on the Colorado River between Lees Ferry and Lake Mead, 2000-2009 all reaches. 

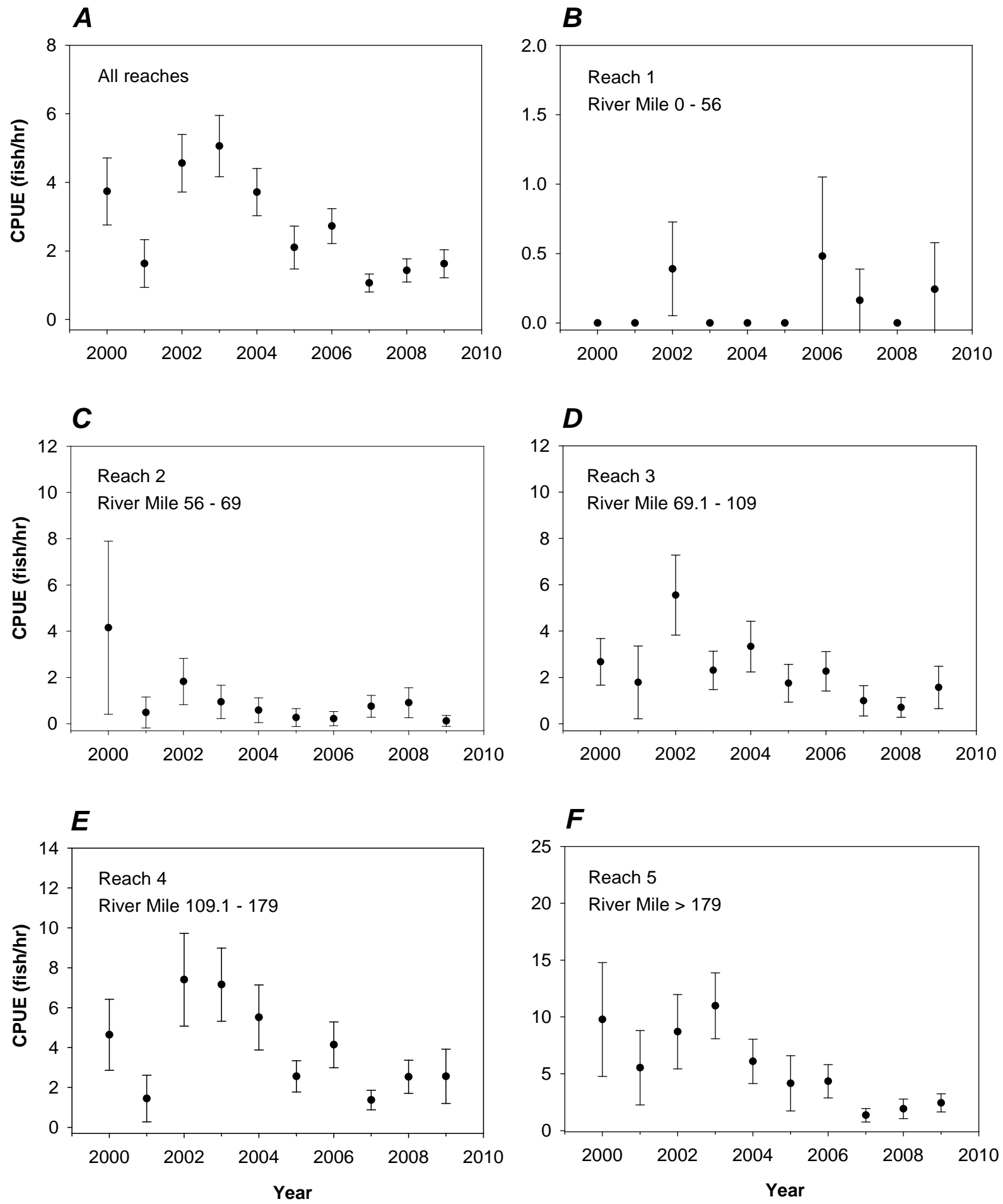

Figure 6. Mean CPUE (catch per hour) of common carp captured during electrofishing surveys on the Colorado River between Lees Ferry and Lake Mead, 2000-2009. A, All reaches. B, Reach 1. C, Reach 2. D, Reach 3. E, Reach 4. F, Reach 5. Bars represent \pm 2 standard errors of the mean (close approximation of $95 \%$ confidence intervals). 

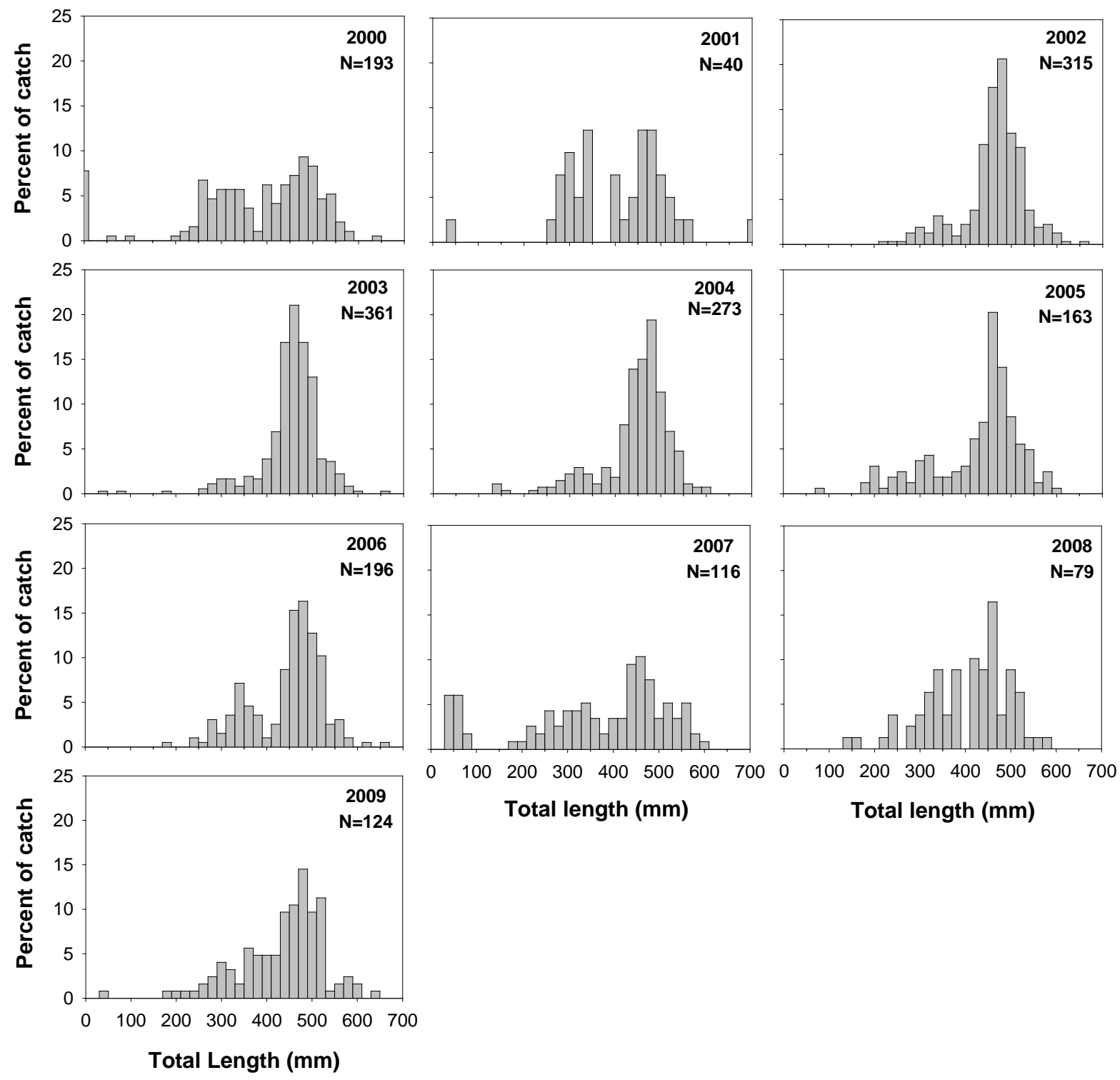

Figure 7. Length-frequency distribution of common carp captured during electrofishing surveys on the Colorado River between Lees Ferry and Lake Mead, 2000-2009 all reaches. 

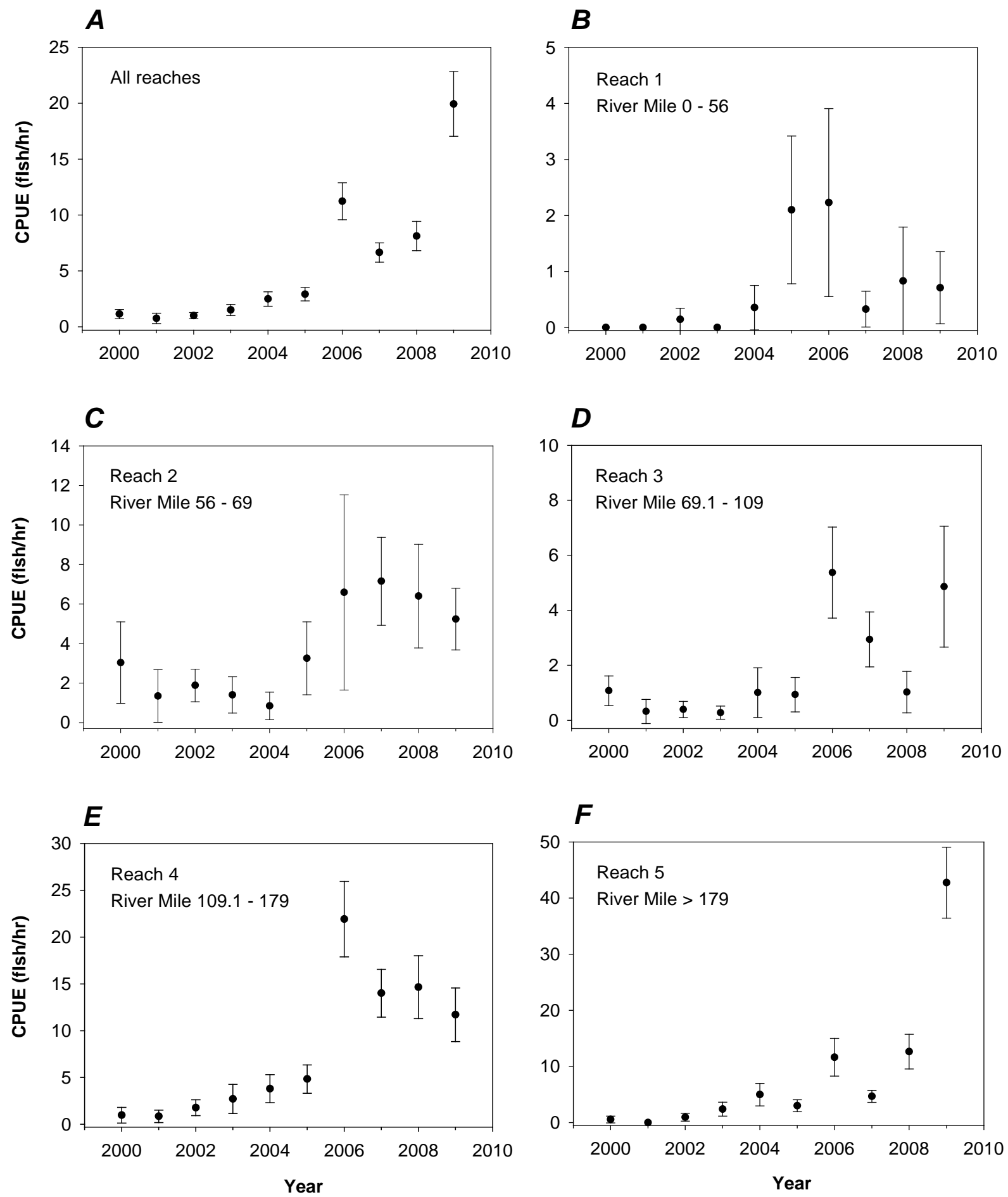

Figure 8. Mean CPUE (catch per hour) of flannelmouth sucker captured during electrofishing surveys on the Colorado River between Lees Ferry and Lake Mead, 2000-2009. A, All reaches. B, Reach 1. C, Reach 2. D, Reach 3. E, Reach 4. F, Reach 5. Bars represent \pm 2 standard errors of the mean (close approximation of $95 \%$ confidence intervals). 

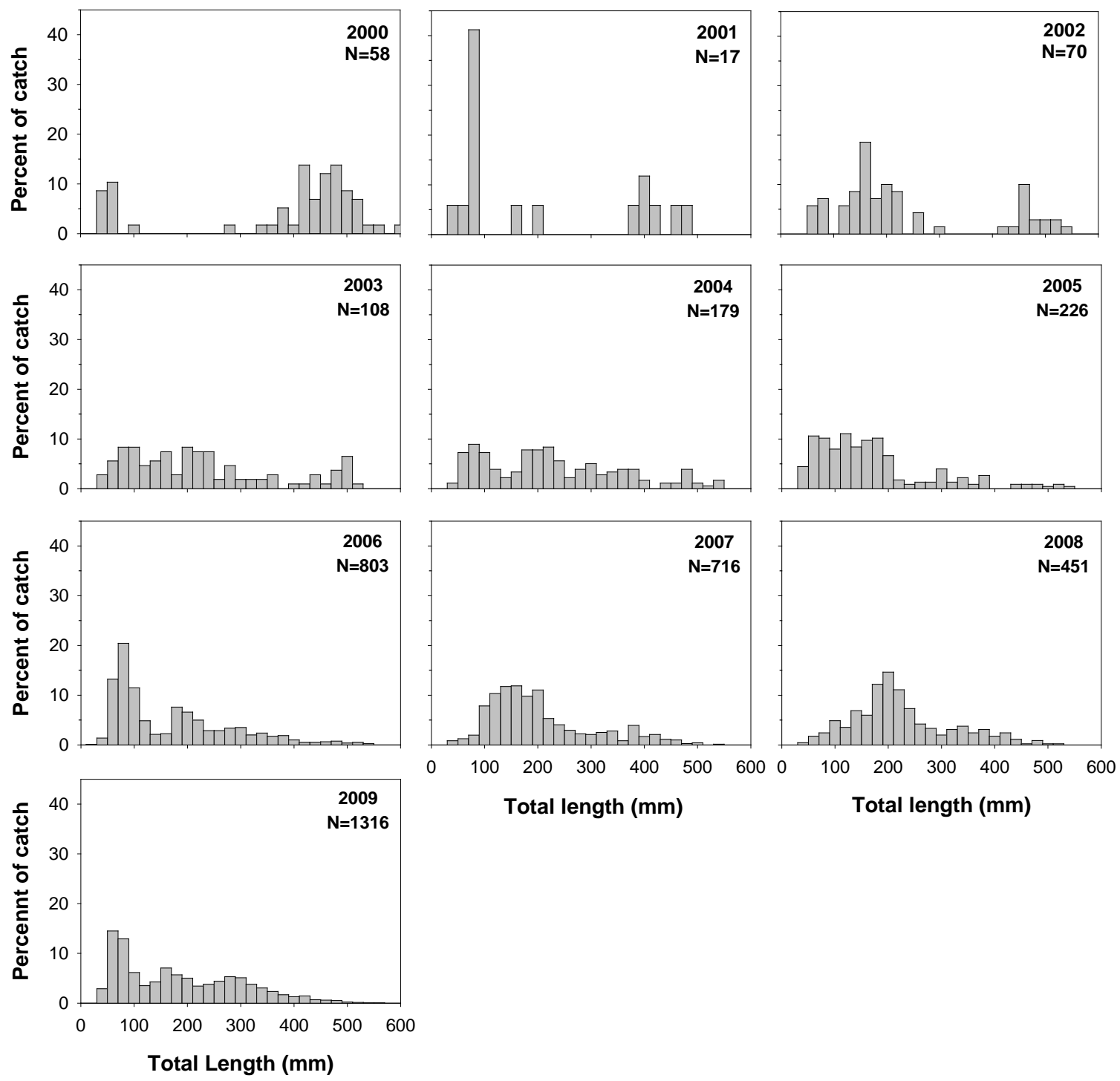

Figure 9. Length-frequency distribution of flannelmouth sucker captured during electrofishing surveys on the Colorado River between Lees Ferry and Lake Mead, 2000-2009 all reaches. 

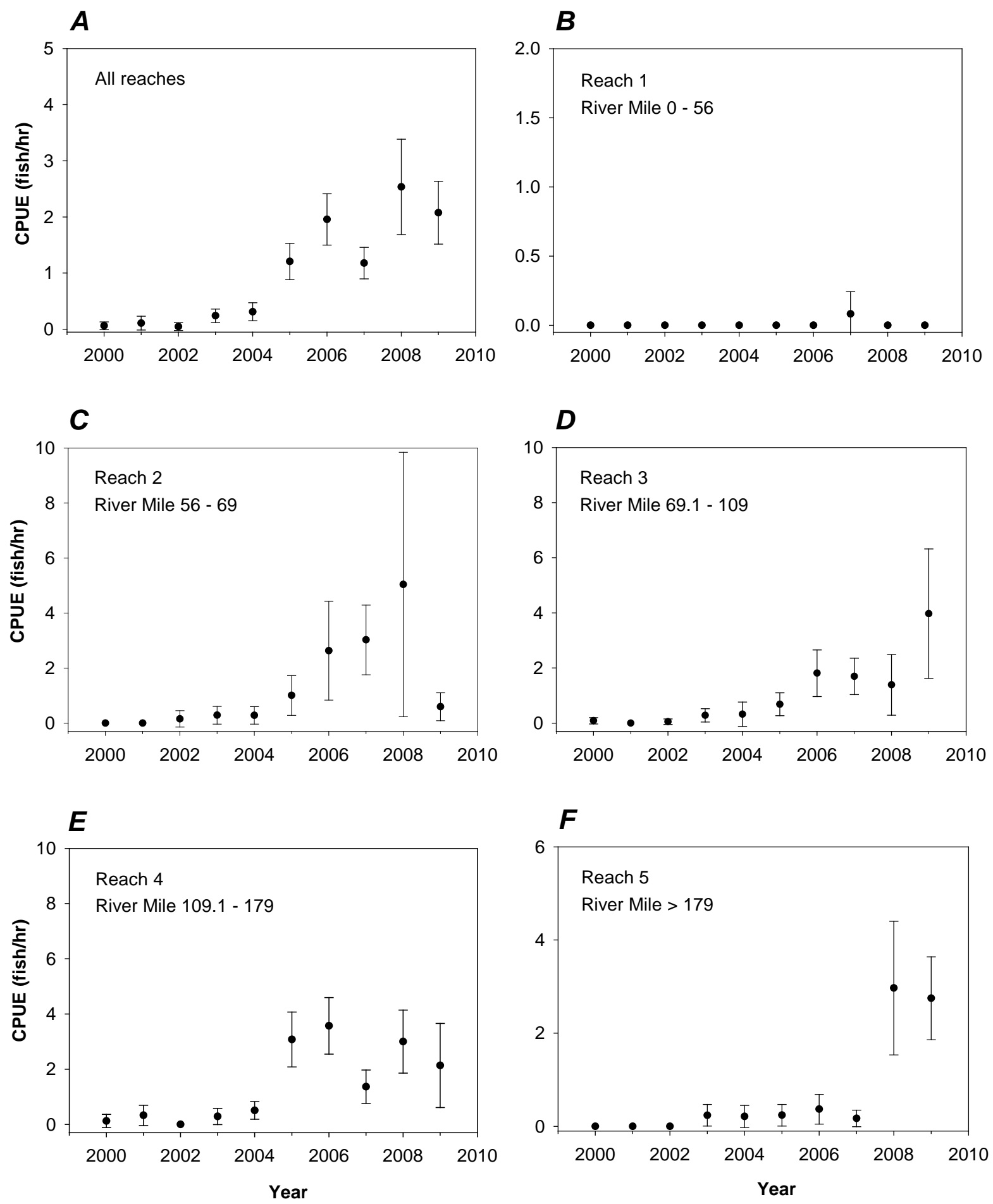

Figure 10. Mean CPUE (catch per hour) of bluehead sucker captured during electrofishing surveys on the Colorado River between Lees Ferry and Lake Mead, 2000-2009. A, All reaches. B, Reach 1. C, Reach 2. D, Reach 3. E, Reach 4. F, Reach 5. Bars represent \pm 2 standard errors of the mean (close approximation of $95 \%$ confidence intervals). 

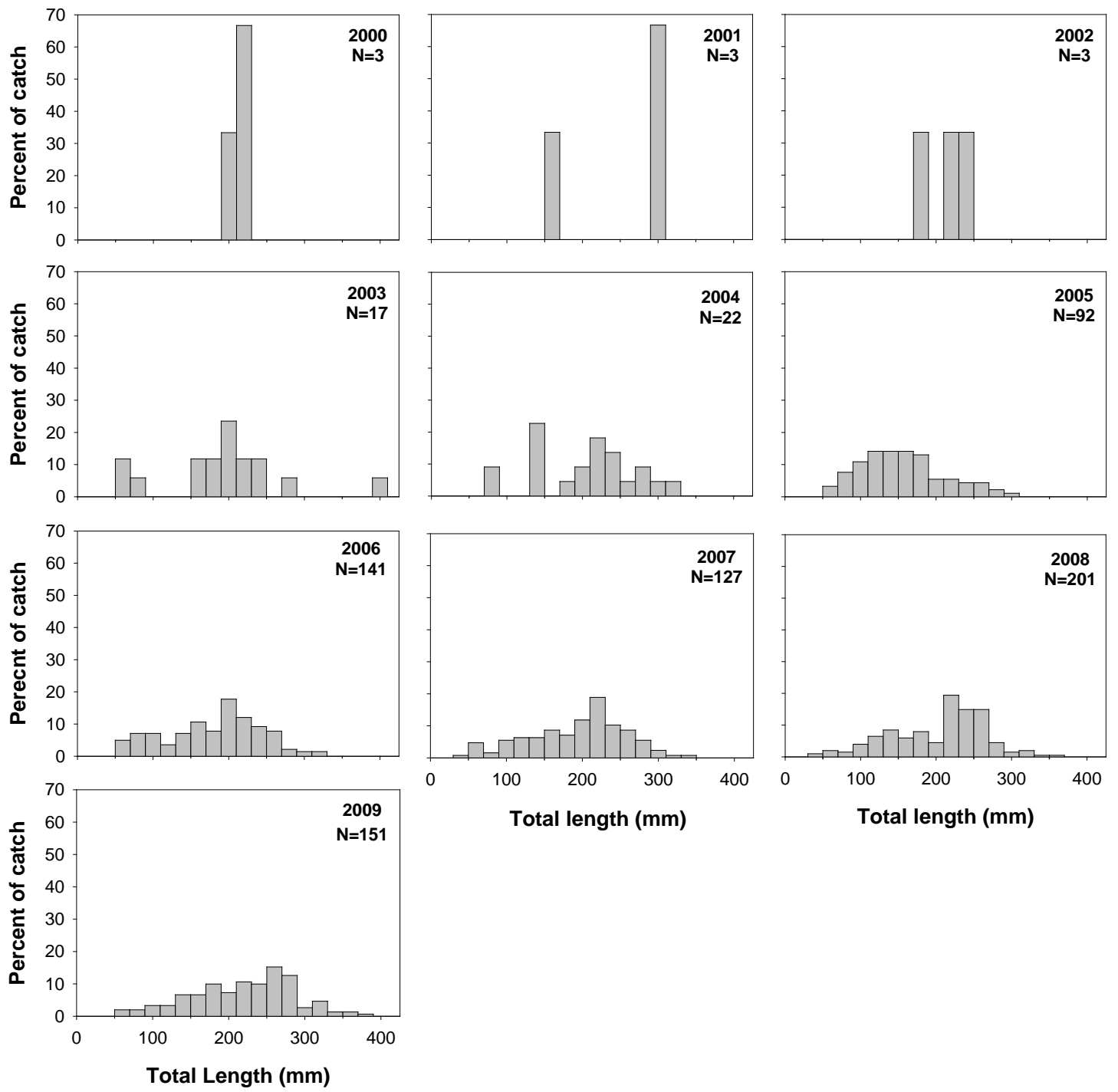

Total length ( $\mathrm{mm}$ )

Figure 11. Length-frequency distribution of bluehead sucker captured during electrofishing surveys on the Colorado River between Lees Ferry and Lake Mead, 2000-2009 all reaches. 

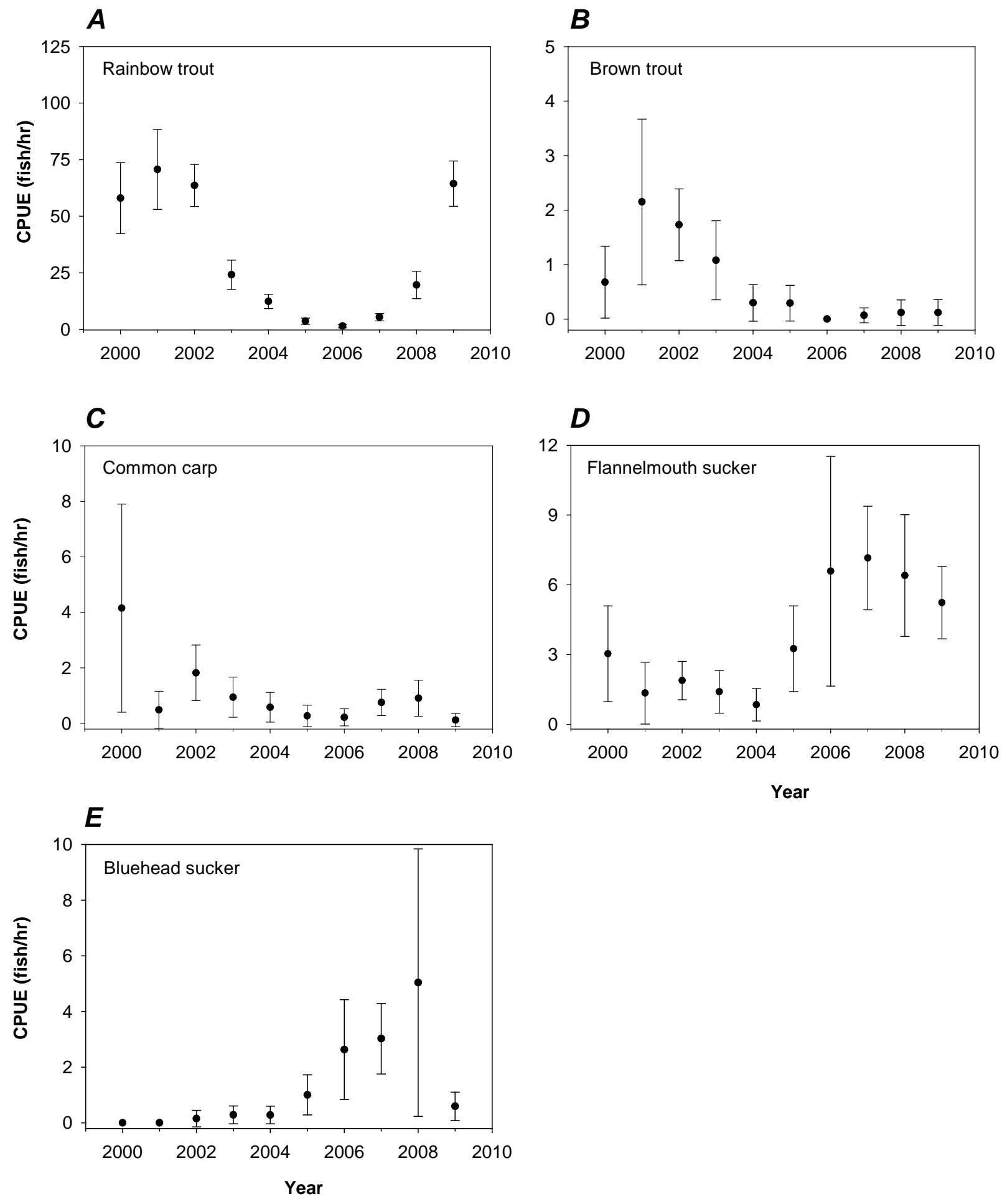

Figure 12. Mean CPUE (catch per hour) of $(A)$ rainbow trout, $(B)$ brown trout, $(C)$ common carp, $(D)$ flannelmouth sucker, and (E) bluehead sucker captured during electrofishing surveys in reach 2 (river mile 56.1-69) of the Colorado River, Grand Canyon, Ariz., 2000-2009. Bars represent \pm 2 standard errors of the mean (close approximation of $95 \%$ confidence intervals). 
Table 1. Sampling information and species composition data collected during the first 2009 Arizona Game and Fish Department long-term monitoring trip.

[L, low; H, high]

\begin{tabular}{|c|c|c|c|c|c|c|c|c|c|c|c|c|c|}
\hline $\begin{array}{c}\text { Sampling } \\
\text { date }\end{array}$ & $\begin{array}{c}\text { Number } \\
\text { of } \\
\text { samples }\end{array}$ & $\begin{array}{l}\text { Start } \\
\text { river } \\
\text { mile } \\
\end{array}$ & $\begin{array}{l}\text { End } \\
\text { river } \\
\text { mile }\end{array}$ & Reach & $\begin{array}{l}\text { Average } \\
\text { seconds }\end{array}$ & Turbidity & $\begin{array}{c}\text { Bluehead } \\
\text { sucker }\end{array}$ & $\begin{array}{c}\text { Brown } \\
\text { trout }\end{array}$ & $\begin{array}{c}\text { Common } \\
\text { carp }\end{array}$ & $\begin{array}{l}\text { Fathead } \\
\text { minnow }\end{array}$ & $\begin{array}{c}\text { Flannel- } \\
\text { mouth } \\
\text { sucker }\end{array}$ & $\begin{array}{c}\text { Rainbow } \\
\text { trout }\end{array}$ & $\begin{array}{c}\text { Speckled } \\
\text { dace }\end{array}$ \\
\hline $2 / 28 / 2009$ & 24 & 17.46 & 18.75 & 1 & 318 & $\mathrm{~L}$ & 0 & 0 & 0 & 0 & 0 & 854 & 0 \\
\hline $3 / 1 / 2009$ & 24 & 37.29 & 38.42 & 1 & 310 & $\mathrm{~L}$ & 0 & 0 & 2 & 0 & 5 & 506 & 0 \\
\hline $3 / 2 / 2009$ & 24 & 56.63 & 59.04 & 2 & 310 & $\mathrm{~L}$ & 2 & 1 & 0 & 0 & 16 & 179 & 0 \\
\hline $3 / 3 / 2009$ & 24 & 57.88 & 58.94 & 2 & 314 & $\mathrm{~L}$ & 1 & 0 & 0 & 0 & 14 & 184 & 1 \\
\hline $3 / 4 / 2009$ & 24 & 65.69 & 68.93 & 2 & 314 & $\mathrm{H}$ & 6 & 0 & 1 & 4 & 6 & 17 & 2 \\
\hline $3 / 5 / 2009$ & 24 & 73.79 & 74.97 & 3 & 311 & $\mathrm{H}$ & 1 & 0 & 1 & 8 & 9 & 14 & 0 \\
\hline $3 / 6 / 2009$ & 24 & 82.40 & 83.38 & 3 & 313 & $\mathrm{H}$ & 1 & 17 & 0 & 0 & 2 & 23 & 0 \\
\hline $3 / 7 / 2009$ & 24 & 90.05 & 91.88 & 3 & 310 & $\mathrm{H}$ & 0 & 34 & 5 & 0 & 7 & 34 & 0 \\
\hline $3 / 8 / 2009$ & 24 & 106.65 & 107.73 & 3 & 316 & $\mathrm{H}$ & 0 & 9 & 1 & 0 & 0 & 22 & 1 \\
\hline $3 / 9 / 2009$ & 24 & 116.56 & 117.63 & 4 & 319 & $\mathrm{H}$ & 0 & 3 & 6 & 0 & 2 & 26 & 0 \\
\hline $3 / 10 / 2009$ & 24 & 119.29 & 120.27 & 4 & 320 & $\mathrm{H}$ & 1 & 1 & 3 & 0 & 9 & 22 & 2 \\
\hline $3 / 11 / 2009$ & 24 & 123.39 & 124.85 & 4 & 320 & $\mathrm{H}$ & 9 & 2 & 1 & 2 & 31 & 31 & 0 \\
\hline $3 / 12 / 2009$ & 24 & 138.70 & 141.62 & 4 & 324 & $\mathrm{H}$ & 4 & 2 & 3 & 0 & 7 & 46 & 16 \\
\hline $3 / 13 / 2009$ & 24 & 167.86 & 169.87 & 4 & 313 & $\mathrm{H}$ & 3 & 2 & 1 & 12 & 31 & 14 & 13 \\
\hline $3 / 14 / 2009$ & 24 & 174.85 & 176.04 & 4 & 318 & $\mathrm{H}$ & 2 & 0 & 2 & 3 & 19 & 9 & 41 \\
\hline $3 / 15 / 2009$ & 30 & 193.29 & 196.46 & 5 & 316 & $\mathrm{H}$ & 9 & 0 & 8 & 3 & 42 & 4 & 65 \\
\hline $3 / 16 / 2009$ & 30 & 212.24 & 216.49 & 5 & 307 & $\mathrm{H}$ & 1 & 0 & 1 & 5 & 25 & 3 & 7 \\
\hline $3 / 17 / 2009$ & 20 & 221.02 & 222.60 & 5 & 309 & $\mathrm{H}$ & 0 & 0 & 2 & 6 & 26 & 2 & 42 \\
\hline Total & & & & & & & 40 & 71 & 37 & 43 & 251 & 1,990 & 190 \\
\hline
\end{tabular}


Table 2. Sampling information and species composition data collected during the second 2009 Arizona Game and Fish Department long-term monitoring trip.

[L, low; H, high]

\begin{tabular}{|c|c|c|c|c|c|c|c|c|c|c|c|c|c|c|c|c|c|}
\hline 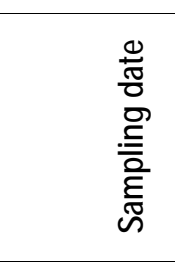 & 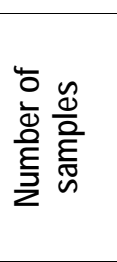 & 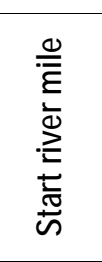 & 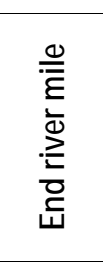 & $\begin{array}{l}\text { ত্ } \\
\mathbb{\Xi} \\
\mathscr{\not}\end{array}$ & 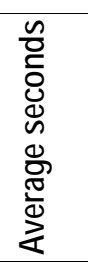 & 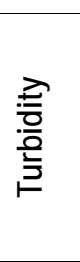 & 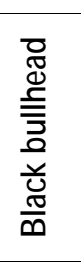 & 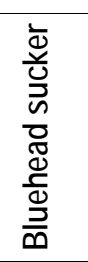 & 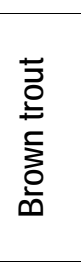 & 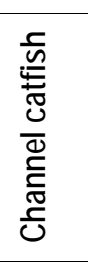 & 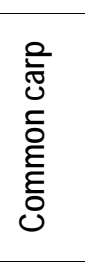 & 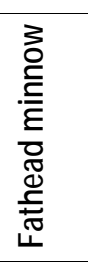 & 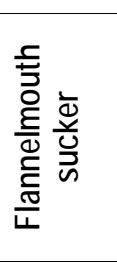 & 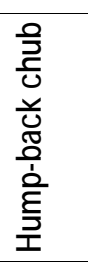 & 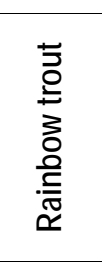 & 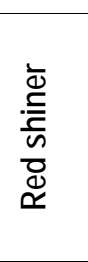 & 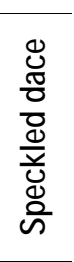 \\
\hline $3 / 26 / 2009$ & 24 & 21.5 & 22.6 & 1 & 322 & $\mathrm{~L}$ & 0 & 0 & 0 & 0 & 0 & 0 & 0 & 0 & 808 & 0 & 0 \\
\hline $3 / 27 / 2009$ & 24 & 46.3 & 48.3 & 1 & 320 & $\mathrm{~L}$ & 0 & 0 & 0 & 0 & 0 & 0 & 1 & 0 & 324 & 0 & 0 \\
\hline $3 / 28 / 2009$ & 24 & 59.0 & 58.9 & 2 & 333 & $\mathrm{~L}$ & 0 & 0 & 0 & 0 & 0 & 0 & 8 & 2 & 100 & 0 & 0 \\
\hline $3 / 29 / 2009$ & -- & -- & -- & -- & -- & $\mathrm{L}$ & -- & -- & -- & -- & -- & -- & -- & -- & -- & -- & -- \\
\hline $3 / 30 / 2009$ & 24 & 60.2 & 61.3 & 2 & 328 & $\mathrm{~L}$ & 1 & 2 & 0 & 0 & 1 & 7 & 6 & 7 & 93 & 0 & 0 \\
\hline $3 / 31 / 2009$ & 24 & 70.2 & 71.6 & 3 & 316 & $\mathrm{~L}$ & 0 & 31 & 1 & 0 & 1 & 31 & 9 & 0 & 26 & 1 & 5 \\
\hline $4 / 1 / 2009$ & 24 & 85.9 & 86.9 & 3 & 318 & $\mathrm{~L}$ & 0 & 2 & 71 & 0 & 5 & 0 & 8 & 1 & 27 & 0 & 1 \\
\hline $4 / 2 / 2009$ & 24 & 86.9 & 89.8 & 3 & 313 & $\mathrm{~L}$ & 0 & 0 & 69 & 0 & 2 & 1 & 15 & 0 & 78 & 0 & 2 \\
\hline 4/3/2009 & 24 & 102.7 & 103.7 & 3 & 320 & $\mathrm{~L}$ & 0 & 0 & 18 & 0 & 5 & 0 & 8 & 0 & 36 & 0 & 0 \\
\hline 4/4/2009 & 26 & 110.1 & 111.3 & 4 & 316 & $\mathrm{~L}$ & 0 & 2 & 8 & 0 & 6 & 0 & 19 & 0 & 125 & 0 & 2 \\
\hline 4/5/2009 & 24 & 132.6 & 133.6 & 4 & 322 & $\mathrm{~L}$ & 0 & 0 & 4 & 0 & 9 & 1 & 17 & 0 & 27 & 0 & 4 \\
\hline 4/6/2009 & 24 & 135.6 & 136.5 & 4 & 317 & $\mathrm{~L}$ & 0 & 3 & 1 & 0 & 3 & 0 & 23 & 0 & 32 & 0 & 1 \\
\hline 4/7/2009 & 24 & 154.1 & 155.5 & 4 & 320 & $\mathrm{~L}$ & 0 & 13 & 3 & 0 & 4 & 0 & 39 & 0 & 28 & 0 & 18 \\
\hline 4/8/2009 & 30 & 181.7 & 183.3 & 5 & 326 & $\mathrm{~L}$ & 0 & 21 & 1 & 1 & 19 & 4 & 94 & 0 & 14 & 0 & 118 \\
\hline 4/9/2009 & 30 & 183.4 & 185.6 & 5 & 320 & $\mathrm{~L}$ & 0 & 13 & 0 & 0 & 10 & 3 & 116 & 1 & 12 & 0 & 176 \\
\hline $4 / 10 / 2009$ & 30 & 206.1 & 208.1 & 5 & 318 & $\mathrm{~L}$ & 0 & 5 & 0 & 2 & 13 & 14 & 102 & 0 & 1 & 0 & 155 \\
\hline $4 / 11 / 2009$ & 20 & 221.2 & 223.4 & 5 & 320 & $\mathrm{~L}$ & 0 & 9 & 0 & 1 & 4 & 7 & 99 & 0 & 3 & 0 & 86 \\
\hline $4 / 12 / 2009$ & 24 & 229.4 & 231.1 & 5 & 319 & $\mathrm{~L}$ & 0 & 2 & 1 & 0 & 1 & 0 & 28 & 0 & 2 & 0 & 18 \\
\hline $4 / 13 / 2009$ & 36 & 239.1 & 243.4 & 5 & 314 & $\mathrm{~L}$ & 0 & 2 & 0 & 0 & 1 & 10 & 115 & 0 & 1 & 119 & 56 \\
\hline $4 / 14 / 2009$ & 36 & 246.4 & 253.8 & 5 & 316 & $\mathrm{~L}$ & 0 & 1 & 0 & 0 & 3 & 16 & 138 & 0 & 0 & 96 & 47 \\
\hline $4 / 15 / 2009$ & 36 & 257.4 & 264.7 & 5 & 316 & $\mathrm{~L}$ & 0 & 6 & 0 & 0 & 1 & 14 & 217 & 0 & 0 & 24 & 31 \\
\hline Total & & & & & & & 1 & 112 & 177 & 4 & 88 & 108 & 1,062 & 11 & 1,737 & 240 & 720 \\
\hline
\end{tabular}


Table 3. Mean CPUE (catch-per-unit-effort) and coefficient of variation (CV, \%) for common large-bodied fishes by species and year, all reaches combined, Colorado River 2000-2009.

\begin{tabular}{|c|c|c|c|c|c|c|c|c|c|c|c|c|}
\hline \multirow[b]{2}{*}{ Year } & \multicolumn{6}{|c|}{ Large-bodied nonnative fishes } & \multicolumn{6}{|c|}{ Large-bodied native fishes } \\
\hline & $\begin{array}{c}\text { Rainbow } \\
\text { trout }\end{array}$ & $\mathrm{CV}$ & $\begin{array}{c}\text { Brown } \\
\text { trout }\end{array}$ & $\mathrm{CV}$ & $\begin{array}{l}\text { Common } \\
\text { carp }\end{array}$ & $\mathrm{CV}$ & $\begin{array}{l}\text { Bluehead } \\
\text { sucker }\end{array}$ & $\mathrm{CV}$ & $\begin{array}{l}\text { Flannel- } \\
\text { mouth } \\
\text { sucker }\end{array}$ & $\mathrm{CV}$ & $\begin{array}{c}\text { Humpback } \\
\text { chub }\end{array}$ & $\mathrm{CV}$ \\
\hline 2000 & 45.5 & $8 \%$ & 13.1 & $11 \%$ & 3.7 & $13 \%$ & 0.1 & $58 \%$ & 1.1 & $19 \%$ & 0.2 & $47 \%$ \\
\hline 2001 & 48.5 & $9 \%$ & 8.9 & $16 \%$ & 1.6 & $22 \%$ & 0.1 & $58 \%$ & 0.7 & $32 \%$ & 0.1 & $100 \%$ \\
\hline 2002 & 40.0 & $5 \%$ & 8.1 & $8 \%$ & 4.6 & $9 \%$ & 0.0 & $75 \%$ & 1.0 & $14 \%$ & 0.1 & $50 \%$ \\
\hline 2003 & 23.0 & $7 \%$ & 7.9 & $10 \%$ & 5.1 & $9 \%$ & 0.2 & $25 \%$ & 1.5 & $17 \%$ & 0.0 & $58 \%$ \\
\hline 2004 & 19.7 & $7 \%$ & 5.3 & $10 \%$ & 3.7 & $9 \%$ & 0.3 & $26 \%$ & 2.5 & $13 \%$ & 0.1 & $33 \%$ \\
\hline 2005 & 11.5 & $10 \%$ & 2.3 & $10 \%$ & 2.1 & $15 \%$ & 1.2 & $14 \%$ & 2.9 & $10 \%$ & 0.2 & $35 \%$ \\
\hline 2006 & 7.5 & $12 \%$ & 0.6 & $17 \%$ & 2.7 & $10 \%$ & 2.0 & $12 \%$ & 11.2 & $7 \%$ & 0.2 & $31 \%$ \\
\hline 2007 & 9.9 & $9 \%$ & 0.6 & $15 \%$ & 1.1 & $13 \%$ & 1.2 & $12 \%$ & 6.6 & $7 \%$ & 0.2 & $27 \%$ \\
\hline 2008 & 22.5 & $9 \%$ & 3.7 & $13 \%$ & 1.4 & $12 \%$ & 2.5 & $17 \%$ & 8.1 & $8 \%$ & 0.1 & $41 \%$ \\
\hline 2009 & 63.0 & $8 \%$ & 3.3 & $17 \%$ & 1.6 & $13 \%$ & 2.1 & $14 \%$ & 19.9 & $7 \%$ & 0.2 & $35 \%$ \\
\hline
\end{tabular}

Table 4. Recapture information for Floy tagged rainbow trout captured during electrofishing surveys on the Colorado River between Lees Ferry and Lake Mead, 2009.

\begin{tabular}{lrrrrrrrr}
\hline Tag number & Date marked & $\begin{array}{c}\text { River } \\
\text { mile } \\
\text { marked }\end{array}$ & $\begin{array}{c}\text { Date } \\
\text { recaptured }\end{array}$ & $\begin{array}{c}\text { River mile } \\
\text { recaptured }\end{array}$ & $\begin{array}{c}\text { Days at } \\
\text { liberty }\end{array}$ & $\begin{array}{c}\text { Mark } \\
\text { length } \\
\text { (mm) }\end{array}$ & $\begin{array}{c}\text { Recapture } \\
\text { length (mm) }\end{array}$ & $\begin{array}{c}\text { Distance } \\
\text { moved (mi) }\end{array}$ \\
\hline USGS 14288 & $2 / 28 / 2009$ & 17.5 & $3 / 26 / 2009$ & 21.6 & 26 & 288 & 293 & 4.1 \\
USGS 17278 & $3 / 3 / 2009$ & 58.7 & $3 / 28 / 2009$ & 59.3 & 25 & 261 & 272 & 0.6 \\
USGS 17864 & $3 / 2 / 2009$ & 57.6 & $3 / 28 / 2009$ & 59.4 & 26 & 283 & 285 & 1.8 \\
\hline
\end{tabular}


Table 5. Trip information from 2000-2009, including flow (cubic feet per second) at Lees Ferry and temperature $\left({ }^{\circ} \mathrm{C}\right.$ ) at river mile 87.

\begin{tabular}{|c|c|c|c|c|c|c|c|c|c|}
\hline Trip & Trip ID & Start date & End date & $\begin{array}{l}\text { No. of } \\
\text { days }\end{array}$ & $\begin{array}{l}\text { Start river } \\
\text { mile }\end{array}$ & End river mile & $\begin{array}{c}\text { Distance } \\
\text { sampled (mi) }\end{array}$ & $\begin{array}{l}\text { Lees Ferry flow } \\
\text { (mean } \pm \text { SD) }\end{array}$ & $\begin{array}{l}\text { River mile } 87 \\
\text { temperature } \\
\text { (mean } \pm \mathrm{SD} \text { ) }\end{array}$ \\
\hline 1 & GC20000604 & $6 / 4 / 2000$ & $6 / 17 / 2000$ & 13 & 20.7 & 221.7 & 201.1 & $8,230 \pm 59$ & $14.8 \pm 0.2$ \\
\hline 2 & GC20000721 & $7 / 21 / 2000$ & $8 / 3 / 2000$ & 13 & 36.2 & 218.7 & 182.5 & $8,378 \pm 51$ & $15.2 \pm 0.1$ \\
\hline 3 & GC20000825 & $8 / 25 / 2000$ & $9 / 5 / 2000$ & 11 & 18.4 & 94.7 & 76.3 & $10,038 \pm 5,660$ & $14.1 \pm 0.3$ \\
\hline 4 & GC20010309 & $3 / 9 / 2001$ & $3 / 18 / 2001$ & 9 & 39.3 & 196.7 & 157.4 & $10,444 \pm 1,561$ & $9.8 \pm 0.2$ \\
\hline 5 & GC20020214 & $2 / 14 / 2002$ & $3 / 3 / 2002$ & 17 & 12.0 & 218.4 & 206.4 & $10,304 \pm 1,706$ & $8.6 \pm 0.3$ \\
\hline 6 & GC20020404 & $4 / 4 / 2002$ & $4 / 20 / 2002$ & 16 & 14.6 & 216.5 & 201.9 & $10,305 \pm 1,414$ & $11.2 \pm 0.3$ \\
\hline 7 & GC20030405 & $4 / 5 / 2003$ & $4 / 21 / 2003$ & 16 & 8.7 & 224.1 & 215.4 & $10,013 \pm 2,219$ & $10.8 \pm 0.7$ \\
\hline 8 & GC20030503 & $5 / 3 / 2003$ & $5 / 20 / 2003$ & 17 & 12.4 & 218.5 & 206.1 & $10,722 \pm 2,275$ & $12.0 \pm 0.6$ \\
\hline 9 & GC20040402 & $4 / 2 / 2004$ & $4 / 19 / 2004$ & 17 & 18.2 & 224.1 & 205.9 & $10,864 \pm 1,879$ & $11.2 \pm 0.4$ \\
\hline 10 & GC20040501 & $5 / 1 / 2004$ & $5 / 17 / 2004$ & 16 & 1.6 & 223.4 & 221.8 & $9,843 \pm 1,905$ & $12.7 \pm 0.5$ \\
\hline 11 & GC20050416 & $4 / 16 / 2005$ & $5 / 3 / 2005$ & 17 & 20.8 & 225.0 & 204.2 & $7,760 \pm 1,697$ & $12.3 \pm 0.3$ \\
\hline 12 & GC20050514 & $5 / 14 / 2005$ & $5 / 30 / 2005$ & 16 & 4.5 & 223.0 & 218.5 & $9,588 \pm 2,015$ & $13.7 \pm 0.5$ \\
\hline 13 & GC20060408 & $4 / 8 / 2006$ & $4 / 25 / 2006$ & 17 & 2.3 & 222.4 & 220.1 & $10,400 \pm 1,631$ & $11.5 \pm 0.3$ \\
\hline 14 & GC20060506 & $5 / 6 / 2006$ & $5 / 22 / 2006$ & 16 & 11.7 & 224.5 & 212.8 & $9,996 \pm 1,682$ & $13.3 \pm 0.6$ \\
\hline 15 & GC20070308 & $3 / 8 / 2007$ & $3 / 27 / 2007$ & 19 & 8.6 & 223.2 & 214.6 & $9,819 \pm 1,382$ & $10.7 \pm 0.3$ \\
\hline 16 & GC20070915 & $9 / 15 / 2007$ & $10 / 3 / 2007$ & 18 & 8.8 & 265.0 & 256.2 & $10,321 \pm 1,957$ & $13.4 \pm 0.5$ \\
\hline 17 & GC20080205 & $2 / 5 / 2008$ & $2 / 24 / 2008$ & 19 & 17.7 & 224.4 & 206.7 & $10,606 \pm 1,400$ & $8.4 \pm 0.4$ \\
\hline 18 & GC20080327 & $3 / 27 / 2008$ & $4 / 16 / 2008$ & 20 & 17.4 & 224.7 & 207.3 & $10,331 \pm 1,803$ & $10.6 \pm 0.4$ \\
\hline 19 & GC20090228 & $2 / 28 / 2009$ & $3 / 17 / 2009$ & 17 & 17.5 & 222.6 & 205.1 & $10,318 \pm 1,547$ & $9.8 \pm 0.4$ \\
\hline 20 & GC20090326 & $3 / 25 / 2009$ & $4 / 16 / 2009$ & 22 & 21.5 & 264.8 & 243.3 & $10,315 \pm 1,839$ & $10.3 \pm 0.6$ \\
\hline
\end{tabular}


This page intentionally left blank 


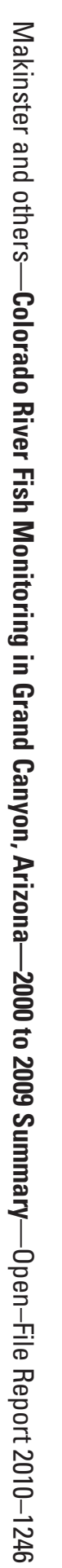

